\title{
Pollen Evidence of Pleistocene and Holocene Vegetation on the Allegheny Plateau, Maryland ${ }^{1}$
}

\author{
Jean A. Maxwell ${ }^{2}$ and Margaret Bryan Davis ${ }^{3}$
}

When the Wisconsin ice sheet stood at its maximum position, tundra vegetation bordered the ice sheet. In the eastern United States, tundra extended at least 300 $\mathrm{km}$ due south of the ice border at $2700 \mathrm{ft}(800 \mathrm{~m})$ elevation on the Allegheny plateau. Spruce and jack (and/or red) pine forest grew at lower elevations in Virginia. On the coastal plain, and farther south, in the piedmont of northern Georgia, jack pine dominated the forest vegetation over a large region.

As the ice sheet receded, the vegetation underwent a series of changes. Coniferous forest was replaced by deciduous forest, beginning 13,600 B.P. in Georgia. The frcquency of white pine began to increase in Virginia at about the same time, and the frequencies of deciduous trees, about $1000 \mathrm{yr}$ later. On the Allegheny plateat, no change took place in the tundra vegetation until 12,700 B.P., when tundra was replaced by open, spruce woodland. Jack and/or red pine grew mixed with, or nearby, the spruce. Pollen from deciduous trees (mainly oak, ash, and hornbeam) reached the site in greater quantity than before. Possibly the increase indicates a change in prevailing wind direction.

On the Allegheny plateau, 10,500 years ago, the boreal woodland was replaced by a mixed coniferous-deciduous forest which included white pine. At about the same time (or perhaps a thousand years later), a similar change occurred in Connecticut. At lower elevations in the Shenandoah Valley, spruce forests including white pine were replaced by oak and other hardwoods.

In the early Holocene, at a time we unfortunately were not able to pinpoint by radiocarbon dating, deciduous forest began to grow on the Allegheny plateau. Later there was a series of changes in the composition of the forest. High frequencies of oak pollen occur throughout the sequence, with successive maxima of hemlock, beech, and finally, hickory. High percentages of chestnut pollen occur with a maximum approximately coincident with the maximum of beech. These changes are probably significant both from stratigraphic and paleoecologic points of view, and should be studied in greater detail at sites where radiocarbon dating will be possible. The early maximum of chestnut pollen is a major difference between the pollen sequence in the Alleghenies and southern and central New England, suggesting that this species was very slow to move northward, arriving in New England just 2000 B.P. as the result of migration, not climatic change.

\section{INTRODUCTION}

The pollen record is becoming increasingly detailed for glaciated portions of the

\footnotetext{
1 Contribution No. 161 of the Great Lakes Research Division, the University of Michigan.

2 Department of Anthropology, the University of Michigan.

${ }^{3}$ Great Lakes Research Division, the University of Michigan, Ann Arbor, MI 48104.
}

eastern United States. Within the next several years, sufficient palynological and radiometric data should be available from the glaciated region to permit a pollen stratigraphic synthesis similar to that recently completed for Minnesota (Cushing, 1967). The ever-increasing number of site analyses already has permitted, in at least broad outline form, reconstruction of vegetation and 
climate along the ice margin and in the deglaciated terrain (Davis, 1965; Wright, 1970).

The data available for the area south of the Wisconsin drift border are, in comparison, meager and of uneven geographical distribution, a condition primarily related to paucity of suitable sampling sites (Whitehead, 1965). There is, nevertheless, evident need for location and analysis of additional sites, particularly sites from a variety of environments. This is a necessary prerequisite not merely for consideration of past vegetation and climate in nonglaciated areas. Solution of broad paleoecological problems such as the integrity of biotic communities during glacial and postglacial times requires evidence from south as well as north of the drift border. The Appalachian region is particularly important because the species richness of forest communities in the region has been a focus for biogeographic discussion. To many ecologists, the diversity of the flora implies a long period of floristic stability and community evolution (Braun, 1950).

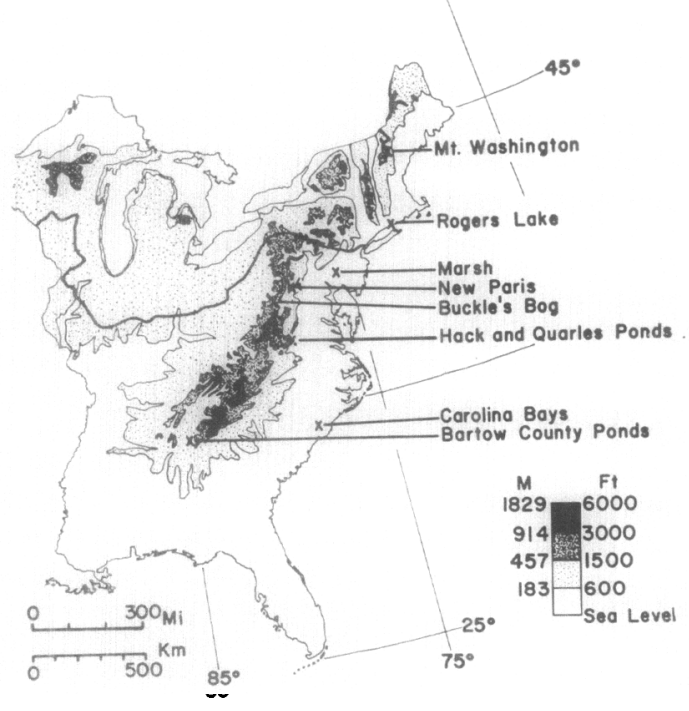

FIG. 1. Map of eastern United States, showing topography and the position of the Wisconsin drift border. Locations of important sites are indicated.
In this paper, we will interpret the character of vegetation of a portion of the Allegheny plateau, beyond the ice border during the last glacial maximum. The series of changes in vegetation leading to the contemporary flora of the area also is discussed. The evidence is from a radiocarbon-dated pollen stratigraphy of Buckle's Bog, Maryland, a site located in upland terrain about $200 \mathrm{~km}$ southeast and $300 \mathrm{~km}$ due south of the Wisconsin drift border. Vegetational interpretation is based on pollen accumulation rates, and comparison of pollen assemblages with surface samples. The pollen evidence provides an important contrast and supplement to recently published data from fullglacial sites at lower elevations in Virginia (Craig, 1969) and farther south in the Carolinas, Georgia, and Florida (Whitehead, 1967; Watts, 1969, 1970).

\section{SITE DESCRIPTION}

Buckle's Bog $\left(39^{\circ} 34^{\prime} \mathrm{N}\right.$ lat, $79^{\circ} 16^{\prime} \mathrm{W}$ long) lies in the northeast-southwest trending valley and ridge topography of the Allegheny plateau (Fig. 1). Meadow Mountain and Negro Mountain, each $3000 \mathrm{ft}$ (about $900 \mathrm{~m}$ ) in elevation, border the broad ridge on which Buckle's Bog is located. The bog itself is situated at $2670 \mathrm{ft}(814 \mathrm{~m})$ elevation and is within $25 \mathrm{~km}$ of the abrupt eastern margin of the plateau (Fig. 2).

The climatic regime of the region is related to the upland topographic situation. The average annual temperature is $9^{\circ} \mathrm{C}, 5$ degrees lower than that of the coastal plain to the east and 3 degrees lower than that of the interior lowland to the west (Visher, 1966). The average July temperature is $20^{\circ} \mathrm{C}$; the average January temperature, $-2^{\circ} \mathrm{C}$ (USDA, 1941). Annual precipitation averages about $1100 \mathrm{~mm}$, equivalent to that received by the moist coastal plain (USDA, 1941).

The presettlement regional vegetation cover was one of extensive forest interspersed with nonforested "glade" areas 


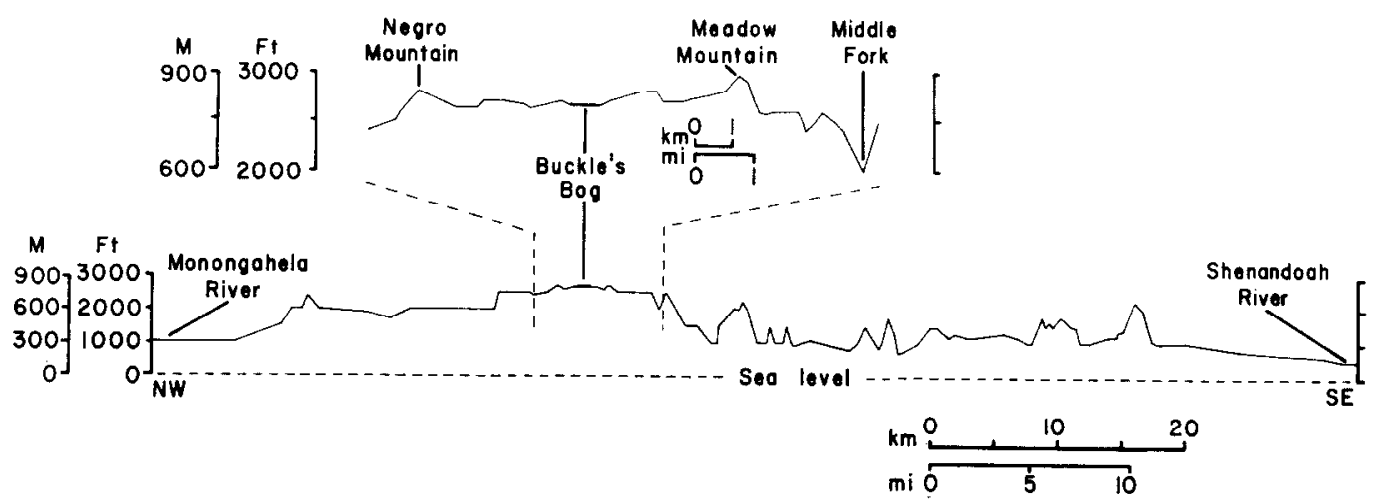

FIG. 2. Section from southwestern Pennsylvania through the Allegheny plateau and the ridge and valley province to the Shenandoah Valley in Virginia. Transect runs from $79^{\circ} 00^{\prime} \mathrm{N}, 39^{\circ} 55^{\prime} \mathrm{W}$ to $78^{\circ} 03^{\prime} \mathrm{N}, 39^{\circ} 00^{\prime} \mathrm{W}$. Vertical exaggeration $\times 8$. From A. M. S. map V 501, $1 / 250,000$, Zone $17: \mathrm{NJ}$ 17-3, Cumberland, 1946, and from Garret County 1/62,500, 1949 revised 1959, Maryland Dept. of Geology, Mines and Water Resources. Detailed insert $\times 3$ scale of remainder of section.

(Shreve, 1910). The forests were composed principally of deciduous trees such as oak (Quercus), chestnut (Castanea), birch (Betula), maple (Acer), and hickory (Carya), although hemlock (Tsuga), pine (Pinus), and spruce (Picea) were present in low frequency. The glades occupied positions at stream headwaters or stream margins. A fringe of coniferous and broadleaf genera such as spruce, pine, hemlock, ash (Fraxi$n u s$ ), maple, and birch surrounded the primarily herbaceous and shrubby vegetation of the glade proper. The herbs and shrubs included grasses (Gramineae), sedges (Cyperaceae), and heaths (Ericaceae) as well as alder (Alnus), Viburnum, and holly (Ilex).

Buckle's Bog is the remnant of a 66-hectare (160-acre) glade which occupied the headwater region of the North Branch of the Castleman River. Peat mining has reduced the areal extent of the bog, and farming and logging have modified or removed much of the surrounding valley and ridge forest. The present bog vegetation, however, approximates in composition that described for presettlement glades (Shreve, 1910). The bog sediments rest on shales of the Conemaugh formation, a unit of the Pennsylvania system (Mathews, 1933).

\section{METHODS}

\section{Field Methods}

A core of sediment $5 \mathrm{~cm}$ in diameter was collected in $50-\mathrm{cm}$ increments with a modified Livingstone piston corer. Recovery varied in completeness, presumably because of friction between the corer's barrel and the sediment, ranging from $50 \%$ for the uppermost segment to $80-90 \%$ for the lowermost segments. Because of the discontinuous nature of the core, all depth measurements on the recovered sediment are necessarily estimates. The depths given in this paper assume that each segment of recovered sediment was obtained from the upper portion of its corresponding drive interval. The resulting stratigraphy later was corroborated in channel samples collected from a pit that was dug into the peat down to the clay layer, ca. $0.7 \mathrm{~m}$ from the point where the core was collected. Sampling was terminated in both cases when a corer could be pushed no farther into the basal clay. The total depth of clay is not known, but we believe most of it was recovered in the first core. The later attempt recovered a similar thickness. The stratigraphy of an open section at the bog's margin suggests that bedrock di- 
rectly underlies the clay at the sampling site.

\section{Laboratory Methods}

Quantitative samples were removed from the core by packing the wet sediment into porcelain spoons of $1 \mathrm{ml}$ capacity. To ascertain the magnitude of variation resulting from packing and spoon size differences, dry weight measurements were made on three series of replicate samples. Coefficient-ofvariation values were in all cases less than $20 \%$ of the mean dry weight for the series.

A measured quantity of Eucalyptus stock suspension was added to each sample. The addition was made prior to chemical treatment in order that any loss of fossil material during preparation would result in loss of both fossil grains and a proportionate number of Eucalyptus grains (Benninghoff,

\begin{tabular}{l} 
number of native pollen \\
grains counted \\
\hline number of Eucalyptus \\
grains counted
\end{tabular}

Quantitative samples also were removed from the core in order to determine the weight per unit volume of organics and inorganics. The samples were first dried and dry weight measurements taken; the samples then were ashed at a temperature of $600^{\circ} \mathrm{C}$. The ash weight is considered to be the weight of inorganics, the dry weight minus the ash weight to be the weight of organics, and the percentage loss on ignition to be the proportion of organic weight to dry weight.

Identifications of pine pollen species were made at ten levels in the profile. Slides were scanned at high magnification, and all pine grains werc tallied as white pine (Pinus strobus) (verrucate sculpture on ventral surface), jack $(P$. banksiana $=P$. divaricata) and/or red pine ( $P$. resinosa) (psilate or scabrate on ventral surface), or unidentifiable (hroken, folded, or covered with
1962). The stock suspension, consisting of Eucalyptus pollen suspended in tertiary butyl alcohol, had been assayed previously for number of grains per milliliter by the aliquot slide method (Davis, 1966). Similar procedures also were applied to the surface sediment samples collected from lakes. Surface samples from moss polsters were not assayed for pollen concentration. All samples were treated with $\mathrm{KOH}$ and acetolyzed as described by Faegri and Iversen (1964). When necessary, $\mathrm{HCl}$ and $\mathrm{HF}$ were used also. Sample residues were mounted on slides in silicone fluid, and a minimum of 200 grains of native terrestrial plant pollen was counted. ${ }^{4}$

Pollen concentration values (numbers of grains per milliliter of wet sediment) were calculated for each level by the method of simple proportions:

$$
\begin{aligned}
& \text { number of native pollen } \\
& \text { grains/ml of sediment } \\
& \text { number of Eucalyptus grains } \\
& \text { added } / \mathrm{ml} \text { of sediment }
\end{aligned}
$$

debris such that ventral surface was not visible). These three proportions were applied to the pine percentages and to the pine influx numbers. Proportions were interpolated for intervening levels in order that the three categories could be plotted separately on the diagrams. Size measurements were also made at one level $(188 \mathrm{~cm})$ to verify the identification of jack and/or red pine. Sixteen grains, at least 15 of which were psilate, had mean size $37.2 \mu \mathrm{m}(s=4.6 \mu \mathrm{m}$, mode $39.0 \mu \mathrm{m})$, corresponding well with Whitehead's (1964) measurement for jack pine $(37.01 \mu \mathrm{m}, s=3.40 \mu \mathrm{m})$. Red pine is not ruled out, however, as it is only slightly

4 For a table showing original pollen counts, order NAPS Document 01957 from ASIS National Auxiliary Publications Servicc, c/o CCM Information Sciences, Inc., 22 W. 34th St., New York, N. Y., 10001, remitting $\$ 2.00$ for microfilms or $\$ 5.00$ for photocopies. 
larger at $40.11 \mu \mathrm{m}, s=3.36 \mu \mathrm{m}$ (ibid.). The uniformly small size of the fossil material makes it unlikely that these grains are from $P$. virginiana, $P$. rigida, or $P$. echinata, which occur in western Maryland today. The pollen of these three species has similar sculpturing but is much larger, $45.65,44.95$, and $46.21 \mu \mathrm{m}$, respectively (ibid.).

\section{RESULTS}

\section{Sediment Stratigraphy}

The loss on ignition curve (Fig. 3) provides a useful description of sediment stratigraphy. There is a gradual transition from inorganic sediment (clay) at the base of the core to highly organic sediment (peat) at the $206-\mathrm{cm}$ level. The peat is finely divided and black to blackish-brown except between 50 and $76 \mathrm{~cm}$, where it is coarser in texture and reddish-brown in color. Inorganic content increases in the uppermost $23 \mathrm{~cm}$. The humified peat above $23 \mathrm{~cm}$ is of extremely fine texture.

\section{Surface Samples}

Collection sites. For use as comparative material, surface samples were collected from

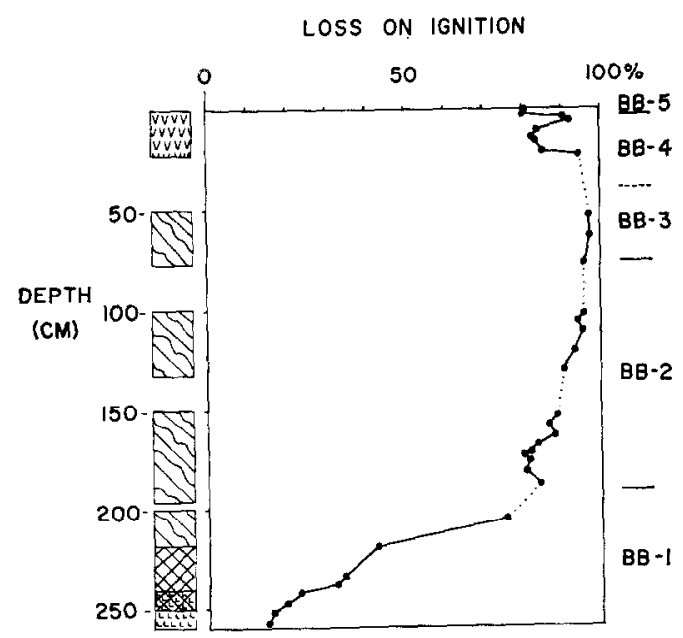

FIG. 3. Percentage of dry weight lost of ignition of sediment samples from the Buckle's Bog profile, plotted against depth in the profile. Key to sediment symbols shown in Fig. 8. seven sites, two on Mount Washington in New Hampshire and five on the Allegheny plateat in the vicinity of Buckle's Bog (Fig. 1).

\section{Mount Washington}

Lake of the Clouds (Coos Co.; New Hampshire ), $5100 \mathrm{ft}(1550 \mathrm{~m})$. Lake of the Clouds is an alpine pond located approx. $1000 \mathrm{ft}(300 \mathrm{~m})$ above the spruce-fir tree line, but at the upper boundary for spruce and fir scrub. Taxa common in the area surrounding the pond include spruce scrub, fir (Abies) scrub, heaths, sedges, grasses, Rosaceae, and Compositae. Scattered birch, willow (Salix), and alder are found also. Sediment samples were taken from the upper $3 \mathrm{~cm}$ of the pond mud near shore.

Hermit Lake (Coos Co., New Hampshire $), 3800 \mathrm{ft}(1160 \mathrm{~m})$. Hermit Lake is a $\operatorname{tarn} 4 \mathrm{ft}$ (ca. $120 \mathrm{~cm}$ ) deep located in spruce-fir forest approx. 200-600 ft $(60-180 \mathrm{~m})$ below the tree line. Taxa common in the area surrounding the tarn include fir, spruce, birch, maple, alder, $V i$ burnum, sedges, grasses, and Rosaceae. Scattered willow and heath are found also. Sediment samples were taken from the upper $3 \mathrm{~cm}$ of the lake mud near the center of the pond.

\section{Allegheny Plateau}

Dolly Sods (Tucker Co., West Virginia), $3950 \mathrm{ft}(1204 \mathrm{~m})$. Dolly Sods is a bog with a flora mainly of Rhododendron, laurel (Kalmia), spruce, and blueberries (Vaccinium). A moss polster was collected from the downwind edge of the bog.

Canaan Mountain (Tucker Co., West Virginia), $3680 \mathrm{ft}(1120 \mathrm{~m})$. Canaan Mountain is a ridge primarily covered by deciduous forest, although marsh and bog conditions are found in places along its crest. A moss polster was collected from an open bog.

Canaan Valley (Tucker Co., West Virginia), $1325 \mathrm{ft}(950 \mathrm{~m})$. The valley is bor- 
dered by Canaan Mountain (3800 ft [1150 $\mathrm{m}]$ ) and Cabin Mountain (4100 ft [1250 $\mathrm{m}]$ ) ridges and is largely under cultivation. A river which meanders through the valley does, however, create sizable marshy tracts. A sphagnum polster was collected from a marshy area distinguished by abundant sedges and surrounded by scattered spruce trees.

Buckle's Bog (Garrett Co., Maryland), $2670 \mathrm{ft}(814 \mathrm{~m})$. The moss polster removed prior to coring of the underlying sediments was saved for surface sample analysis.

Swallow Falls (Garrett Co., Maryland), $2340 \mathrm{ft}(713 \mathrm{~m})$. A mixed coniferous (principally hemlock)-deciduous forest covers the rocky banks of the Youghiogheny River. A sphagnum polster was collected beside the river just behind the crest of the falls.

\section{Surface Sample Assemblages}

The samples collected above timberline on Mount Washington differ markedly from the samples collected below timberline in their higher frequencies of hemlock and sedge pollen, lower frequencies of fir, and lower ratio of spruce to pine pollen (Fig. 4, Table 1). The spruce/pine ratios of the Mount Washington samples follow the pattern delineated by Maher (1963) for the Animas Valley region in the San Juan Mountains, Colorado, in which a declining ratio characterized surface samples collected along a transect through the upper montane spruce forest (spruce/pine $>1$ ), across timberline, and into the alpine zone (spruce/pine $<1$ ). The Mount Washington surface samples are distinctly different from the samples collected on the Allegheny plateau. The former have much higher frequencies of spruce, fir, and birch pollen and lower frequencies of oak, hickory, and ragweed (Ambrosia) pollen. Although the Allegheny plateau spectra do not differ sharply among themselves, the Canaan Mountain sample is distinguishable from the others by its higher frequency of spruce pollen.

\section{Radiocarbon Dates and Sedimentation Rate}

Six sediment samples from the core were submitted to the radiocarbon-dating laboratory at Yale. Their radiocarbon ages are as follows (Minze Stuiver, University of Washington, personal communication):

$\begin{array}{cccr}\text { Y-2436 } & 71-76 \mathrm{~cm} & 10,530 \pm 160 \\ \mathrm{Y}-2612 & 158-165 & 12,320 & 200 \\ \mathrm{Y}-2437 & 188-195 & 12,640 & 200 \\ \mathrm{Y}-2613 & 240-244 & 15,900 & 240 \\ \mathrm{Y}-2619 & 246-252 & 17,400 & 240 \\ \mathrm{Y}-2438 & 252-258 & 18,550 & 250 .\end{array}$

In Fig. 5, the dates are plotted against depth in the profile. The slopes of lines connecting the points on the graph indicate sedimentation rate. Sedimentation of clay was very slow (approx $200 \mathrm{yr} / \mathrm{cm}$ thickness) be-

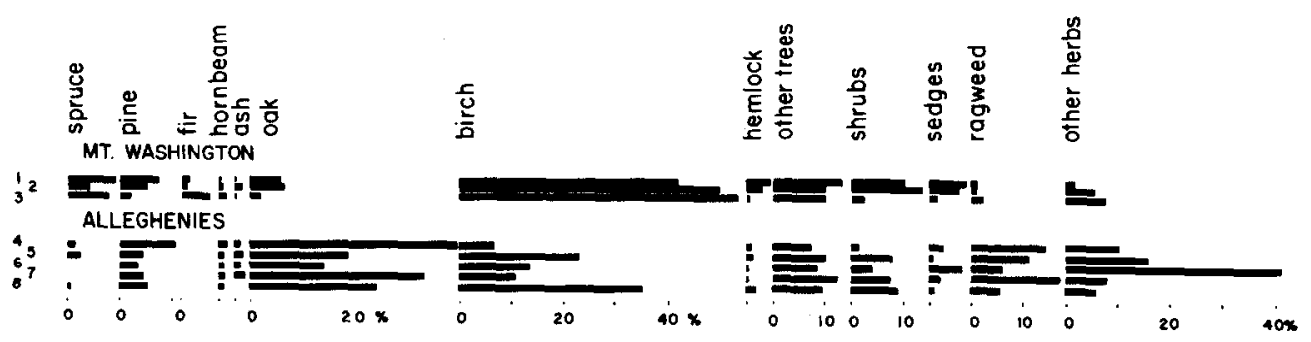

FIG. 4. Pollen percentages in surface samples. Samples 1 and 2 are from Lake of the Clouds, Mt. Washington, $\mathrm{NH}(1550 \mathrm{~m})$. Sample 3 is from Hermit Lake, Mt. Washington, $\mathrm{NH}$ (1160 m). Sample 4 is from Dolly Sods, WV (1204 m) ; sample 5, Canaan Mountain, WV (1120 m) ; sample 6, Canaan Valley, WV $(950 \mathrm{~m})$. Sample 7 is from Buckle's Bog, MD $(814 \mathrm{~m})$; sample 8, Swallow Falls, MD $(713 \mathrm{~m})$. Complete data are given in Table 1. 
TABLE 1

Pollen Percentages in Surface Samples from Mt. Washington, in the White Mountains of New Hampshike, and from the Allegheny Plateau

\begin{tabular}{|c|c|c|c|c|c|c|c|c|c|c|c|c|c|c|c|c|}
\hline \multirow{3}{*}{ Pollen sample } & \multicolumn{6}{|c|}{ Mt. Washington, $\mathrm{NH}$} & \multicolumn{4}{|c|}{ Alleghenies } & \multirow{2}{*}{\multicolumn{2}{|c|}{$\begin{array}{l}\text { Canaan } \\
\text { Valley }\end{array}$}} & \multirow{2}{*}{\multicolumn{2}{|c|}{$\begin{array}{c}\text { Buckle's } \\
\text { Bog }\end{array}$}} & \multirow{2}{*}{\multicolumn{2}{|c|}{$\begin{array}{c}\text { Swallow } \\
\text { Falls }\end{array}$}} \\
\hline & \multicolumn{4}{|c|}{ Lake of the Clouds } & \multicolumn{2}{|c|}{$\begin{array}{l}\text { Hermit } \\
\text { Lake }\end{array}$} & \multicolumn{2}{|c|}{$\begin{array}{l}\text { Dolly } \\
\text { Sods }\end{array}$} & \multicolumn{2}{|c|}{$\begin{array}{c}\text { Canaan } \\
\text { Mt. }\end{array}$} & & & & & & \\
\hline & $\#$ & $\%$ & \# & $\%$ & $\#$ & $\%$ & \# & $\%$ & $\#$ & $\%$ & \# & $\%$ & $\#$ & $\%$ & $\#$ & $\%$ \\
\hline Pinus & 36 & 7.5 & 21 & 5.3 & 9 & 1.9 & 19 & 10.8 & 30.5 & 4.6 & 21 & 3.7 & 32.5 & 4.4 & 11 & 5.5 \\
\hline Picea & 44 & 9.2 & 16 & 4.1 & 16 & 7.7 & 2.5 & 1.4 & 16.5 & 2.5 & 1 & 0.2 & & & 1 & 0.5 \\
\hline Abies & 7.5 & 1.6 & 3.5 & 0.9 & 11 & 5.3 & & & & & 1 & 0.2 & & & & \\
\hline Tsuga & 22 & 4.6 & 12 & 3.0 & 1 & 0.5 & 2 & 1.1 & 8 & 1.2 & 2 & 0.3 & 2 & 0.3 & 4 & 2.0 \\
\hline Juniperus-Thuja & 1 & 0.2 & & & & & & & 1 & 0.1 & & & & & & \\
\hline Populus & & & & & 1 & 0.5 & & & 1 & 0.1 & 2 & 0.3 & 2 & 0.3 & 1 & 0.5 \\
\hline Quercus & 28 & 5.9 & 25 & 6.3 & 4 & 1.9 & 70 & 39.7 & 125 & 18.8 & 80 & 14.0 & 244 & 33.4 & 49 & 24.4 \\
\hline Ostrya-Carpinus & 3 & 0.6 & 3 & 0.8 & 3 & 1.4 & 3 & 1.7 & 7 & 1.1 & 6 & 1.1 & 8 & 1.1 & 2 & 1.0 \\
\hline Betula & 201 & 42.1 & 197 & 49.9 & 111 & 53.4 & 12 & 6.8 & 154 & 23.1 & 77 & 13.5 & 79 & 10.8 & 71 & 35.3 \\
\hline Fraxinus & 2 & 0.3 & 6 & 1.5 & 1 & 0.5 & 2 & 1.1 & 11 & 1.7 & 6 & 1.1 & 14 & 1.9 & & \\
\hline Fagus & 32 & 6.7 & 13 & 3.3 & 5 & 2.4 & 1 & 0.6 & 5 & 0.8 & 9 & 1.6 & 8 & 1.1 & 3 & 1.5 \\
\hline Acer rubrum & & & & & & & & & 4 & 0.6 & 4 & 0.7 & 6 & $0.8\}$ & 2 & 10 \\
\hline Acer saccharum & 17 & 3.6 & 4 & 1.0 & 4 & 1.9 & & & 6 & 0.9 & 4 & 0.7 & 3 & 0.4 & 2 & 1.0 \\
\hline Acer saccharinum & & & 2 & 0.5 & & & & & 2 & 0.3 & 3 & 0.5 & 2 & 0.3 & & \\
\hline Other Acer & & & 1 & 0.3 & & & & & 1 & 0.1 & 1 & 0.2 & & & & \\
\hline Ulmus & 4 & 0.8 & 2 & 0.5 & & & 5 & 2.8 & 10 & 1.5 & 4 & 0.7 & 32 & 4.9 & & \\
\hline Carya & & & 1 & 0.3 & & & 6 & 3.4 & 11 & 1.7 & 7 & 1.2 & 16 & 2.2 & 4 & 2.0 \\
\hline Juglans & 1 & 0.2 & & & & & 1 & 0.6 & 4 & 0.6 & 7 & 1.2 & 7 & 1.0 & 2 & 1.0 \\
\hline Castanea & & & 2 & 0.5 & & & & & 1 & 0.1 & & & 1 & 0.1 & 2 & 1.0 \\
\hline Tilia & & & & & 2 & 1.0 & & & 1 & 0.1 & 2 & 0.3 & & & & \\
\hline Nyssa & & & & & & & & & 1 & 0.1 & 1 & 0.2 & 1 & 0.1 & & \\
\hline Platanus & & & 1 & 0.3 & & & & & 4 & 0.6 & 3 & 0.5 & 2 & 0.3 & 1 & 0.5 \\
\hline Celtis & & & & & & & & & 1 & 0.1 & 1 & 0.2 & 1 & 0.1 & & \\
\hline Betulaceae undiff. & 8 & 1.7 & 14 & 3.5 & 8 & 3.8 & & & 14 & 2.1 & 2 & 0.3 & 6 & 0.8 & 4 & 2.0 \\
\hline Liquidambar & & & & & 1 & 0.5 & & & 2 & 0.3 & & & & & & \\
\hline Alnus & 7 & 1.5 & 11 & 2.8 & 3 & 1.4 & & & 8 & 1.2 & 8 & 1.4 & 15 & 2.1 & 11 & 5.5 \\
\hline Salix & & & 1 & 0.3 & & & 1 & 0.6 & 6 & 0.9 & 3 & 0.5 & 2 & 0.3 & 2 & 1.0 \\
\hline Ericaceae & 3 & 0.6 & 4 & 1.0 & & & & & 4 & 0.6 & & & & & 1 & 0.5 \\
\hline Ilex & & & & & & & 1 & 0.6 & & & & & 14 & 1.9 & 1 & 0.5 \\
\hline Rosaceae & & & 2 & 0.5 & 1 & 0.5 & & & 32 & 4.8 & 10 & 1.8 & 18 & 2.5 & 1 & 0.5 \\
\hline Corylus & & & & & 1 & 0.5 & & & 2 & 0.3 & & & 1 & 0.1 & & \\
\hline Viburnum & & & & & & & 1 & 0.6 & & & 2 & 0.3 & & & 2 & 1.0 \\
\hline Cornus & & & & & & & & & & & & & 3 & 0.4 & & \\
\hline Rhus & & & & & & & & & & & & & 1 & 0.1 & & \\
\hline Vitis & & & & & & & & & 1 & 0.1 & & & 2 & 0.3 & & \\
\hline Gramineae & 5 & 1.0 & 16 & 4.1 & 14 & 6.7 & 5 & 2.8 & 34 & 5.1 & 18 & 3.2 & 23 & 3.1 & 6 & 3.0 \\
\hline Cyperaceae & 33 & 6.9 & 22 & 5.6 & 3 & 1.4 & 5 & 2.8 & 5 & 0.8 & 36 & 6.3 & 15 & 2.1 & 2 & 1.0 \\
\hline Ambrosia & 5 & 1.0 & 4 & 1.0 & 5 & 2.4 & 25 & 14.2 & 74 & 11.1 & 33 & 5.8 & 124 & 17.0 & 11 & 5.5 \\
\hline Rumex & 1 & 0.2 & 1 & 0.3 & & & & & 4 & 0.6 & 3 & 0.5 & 12 & 1.6 & 1 & 0.5 \\
\hline Tubulifloreae & & & 1 & 0.3 & 1 & 0.5 & 7 & 4.0 & 57 & 8.6 & 203 & 35.6 & 3 & 0.4 & 3 & 1.5 \\
\hline Artemisia & & & & & 1 & 0.5 & & & 1 & 0.1 & 3 & 0.5 & 1 & 0.1 & 1 & 0.5 \\
\hline Thalictrum & & & 1 & 0.3 & & & & & & & & & & & 1 & 0.5 \\
\hline Chenopodiaceae & 1 & 0.2 & 2 & 0.5 & & & 2 & 1.1 & 2 & 0.3 & & & 4 & 0.5 & & \\
\hline Caryophyllac & & & & & & & & & & & & & & & & \\
\hline Plantago major & & & & & & & & & & & & & 1 & 0.1 & & \\
\hline Plantago lanceolata & 1 & 0.2 & & & & & 4 & 2.3 & 4 & 0.6 & 4 & 0.7 & 14 & 1.9 & & \\
\hline Labiatae & & & & & & & & & 2 & 0.3 & & & & & & \\
\hline Umbelliferae & & & & & & & & & & & & & 1 & 0.1 & & \\
\hline Unidentifiable & 6 & 1.3 & 6 & 1.5 & 6 & 2.9 & & & 9 & 1.4 & & & 10 & 1.4 & 1 & 0.5 \\
\hline Unknown & & & & & 1 & 0.5 & 2 & 1.1 & & & 3 & 0.5 & & & & \\
\hline Tntal & 477.5 & & 394.5 & & 208 & & 176.5 & & 606 & & 570 & & 730.5 & & 201 & \\
\hline Total trees & 422.5 & 88.5 & 334.5 & 84.8 & & & 123.5 & 70.0 & & & & & & & & \\
\hline Total shrubs & 49 & 10.3 & 54 & 13.7 & & & 3 & 1.7 & & & & & & & & \\
\hline Total herbs & 6 & 1.3 & 6 & 1.5 & & & 50 & 28.3 & & & & & & & & \\
\hline Grains/ml & & & 490,000 & & 8,000 & & & & & & & & & & & \\
\hline Filices & 4 & & 3 & & 1 & & 1 & & & & & & & & & \\
\hline Sphagnum & 1 & & & & 1 & & 210 & & & & 5 & & & & & \\
\hline Osmunda & 1 & & & & & & & & & & & & & & & \\
\hline
\end{tabular}


TABLE 1-Continued

Pollen Percentages in Surface Samples from Mt. Washington, in the White Mountains of New Hampshire, and from the Allegheny Plateau

\begin{tabular}{|c|c|c|c|c|c|c|c|c|c|c|c|c|c|c|c|}
\hline \multirow{4}{*}{ Pollen sample } & \multicolumn{6}{|c|}{ Mt. Washington, NH } & \multicolumn{3}{|c|}{ Alleghenies } & \multirow{3}{*}{\multicolumn{2}{|c|}{$\begin{array}{l}\text { Canaan } \\
\text { Valley }\end{array}$}} & \multirow{3}{*}{\multicolumn{2}{|c|}{$\begin{array}{l}\text { Buckle's } \\
\text { Bog }\end{array}$}} & \multirow{3}{*}{\multicolumn{2}{|c|}{$\begin{array}{c}\text { Swallow } \\
\text { Falls }\end{array}$}} \\
\hline & \multirow{2}{*}{\multicolumn{4}{|c|}{$\begin{array}{l}\text { Lake of the Clouds } \\
\text { Sample } 1 \text { Sample } 2\end{array}$}} & \multirow{2}{*}{\multicolumn{2}{|c|}{$\begin{array}{c}\text { Hermit } \\
\text { Lake }\end{array}$}} & \multirow{2}{*}{\multicolumn{2}{|c|}{$\begin{array}{l}\text { Dolly } \\
\text { Sods }\end{array}$}} & \multirow{2}{*}{$\begin{array}{c}\text { Canaan } \\
\text { Mt. }\end{array}$} & & & & & & \\
\hline & & & & & & & & & & & & & & & \\
\hline & $\#$ & $\%$ & $\#$ & $\%$ & $\#$ & $\%$ & $\#$ & $\%$ & $\# \%$ & $\#$ & $\%$ & $\#$ & $\%$ & $\#$ & $\%$ \\
\hline Lycopodium & & & 3 & & 2 & & & & & 3 & & & & & \\
\hline Nymphaea & ? & & & & & & & & & & & & & & \\
\hline Myriophyllum & & & 1 & & (1) & & 1 & & & 2 & & & & & \\
\hline Typhaceae & & & & & & & 2 & & & & & & & & \\
\hline Potamogeton & & & & & 1 & & & & & & & & & & \\
\hline Sparganium & & & & & & & 1 & & & & & & & & \\
\hline
\end{tabular}

tween 18,000 and 15,000 B.P. The sediments then became more organic, and sedimentation rate increased. The fibrous peat, which makes up the bulk of the peat body at Buckle's Bog, was deposited rapidly (10-20 $\mathrm{yr} / \mathrm{cm}$ ) between 12,000 and 10,000 B.P. A dashed line indicating this deposition has been extended a few centimeters above the highest radiocarbon sample because we assume that similar deposition rate characterizes the entire thickness of fibrous peat. Extrapolating from the top of the fibrous peat to the surface, where peat is forming now, we find that about $50 \mathrm{~cm}$ of peat has formed over the last $10,000 \mathrm{yr}$-an extraordinarily slow deposition rate of ca. $200 \mathrm{yr} / \mathrm{cm}$. Deposition appears to have been continuous, as the pollen stratigraphy shows a series of changes correlative with those found at other sites. There is every reason to believe that the upper three dates are reliable, since they are based on the radiocarbon content of fibrous terrestrial peat. We feel less confidence in the three older dates, from waterlaid sediment. Since there are Paleozoic shales in the vicinity, the ancient lake might have contained a certain amount of ${ }^{14} \mathrm{C}$-deficient carbonate in solution, derived from these rocks. Often the error from this source in the organic fraction of lake sediments can be estimated from carbon assays of surface mud (Deevey et al., 1954; Broecker and Walton, 1959). There is no opportunity for this at our site, since limnic sediments are no longer being formed.

\section{Pollen Concentration and Rates of Pollen and Sediment Infiux}

Pollen concentration (Fig. 6) is surprisingly high in the basal clay, about 300,000 grains $/ \mathrm{ml}$. In the overlying peat, the concentration drops to about 50,000 grains/ml (at

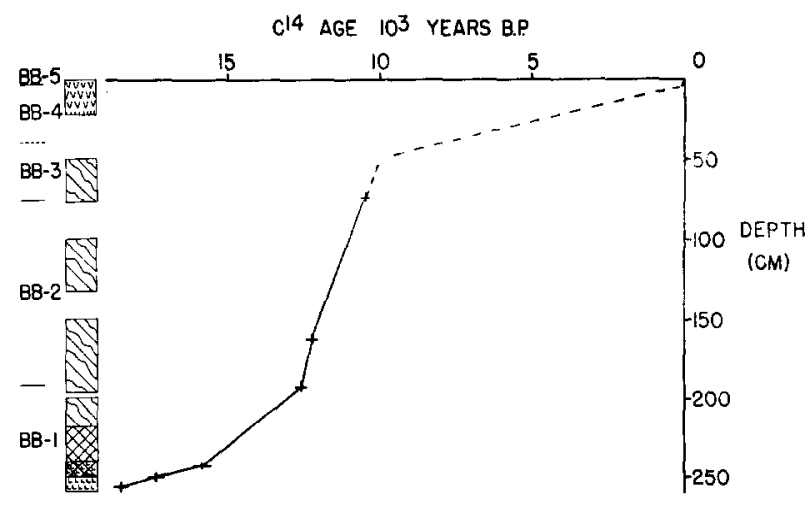

FIG. 5. Radiocarbon ages of samples from the Buckle's Bog profile plotted against depth in the profile. The slopes of the lines connecting the points are a measure of sedimentation rate. 


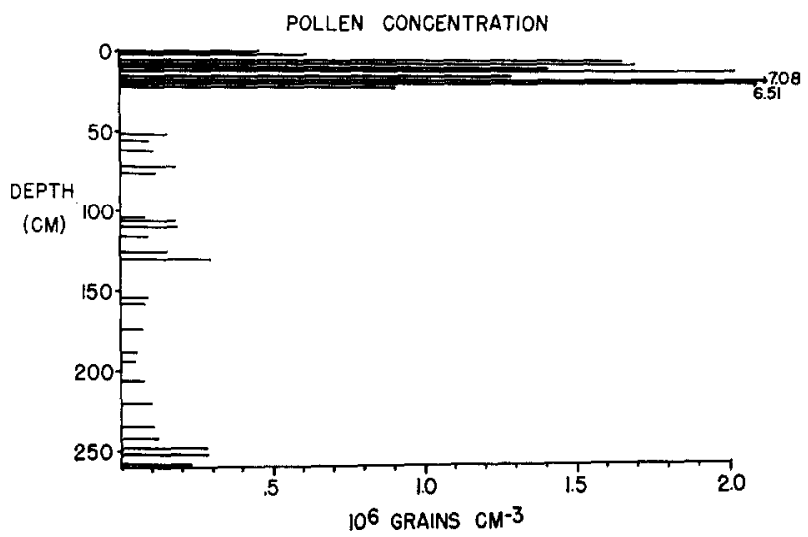

FIG. 6. Pollen concentration (numbers of grains per milliliter wet sediment) plotted against depth in the profile.

approx $200 \mathrm{~cm}$ depth), increasing again to 200,000-300,000 grains/ml above the 130$\mathrm{cm}$ level. Values reach 6-7 million grains $/ \mathrm{ml}$ in the upper humified peat.

The basal clay was deposited over a long time interval at the rate of $200 \mathrm{yr} / \mathrm{cm}$ thickness (Fig. 5). In Fig. 7, the right-hand column shows the influx of pollen, i.e., the numbers that accumulated per square centimeter of sediment surface per year. This variable was calculated by dividing the pollen concentration per milliliter by the number of years represented by a centimeter thickness of sediment (Davis and Deevey, 1964). The ordinate shows the ahsolute age of the sediment. Pollen influx was
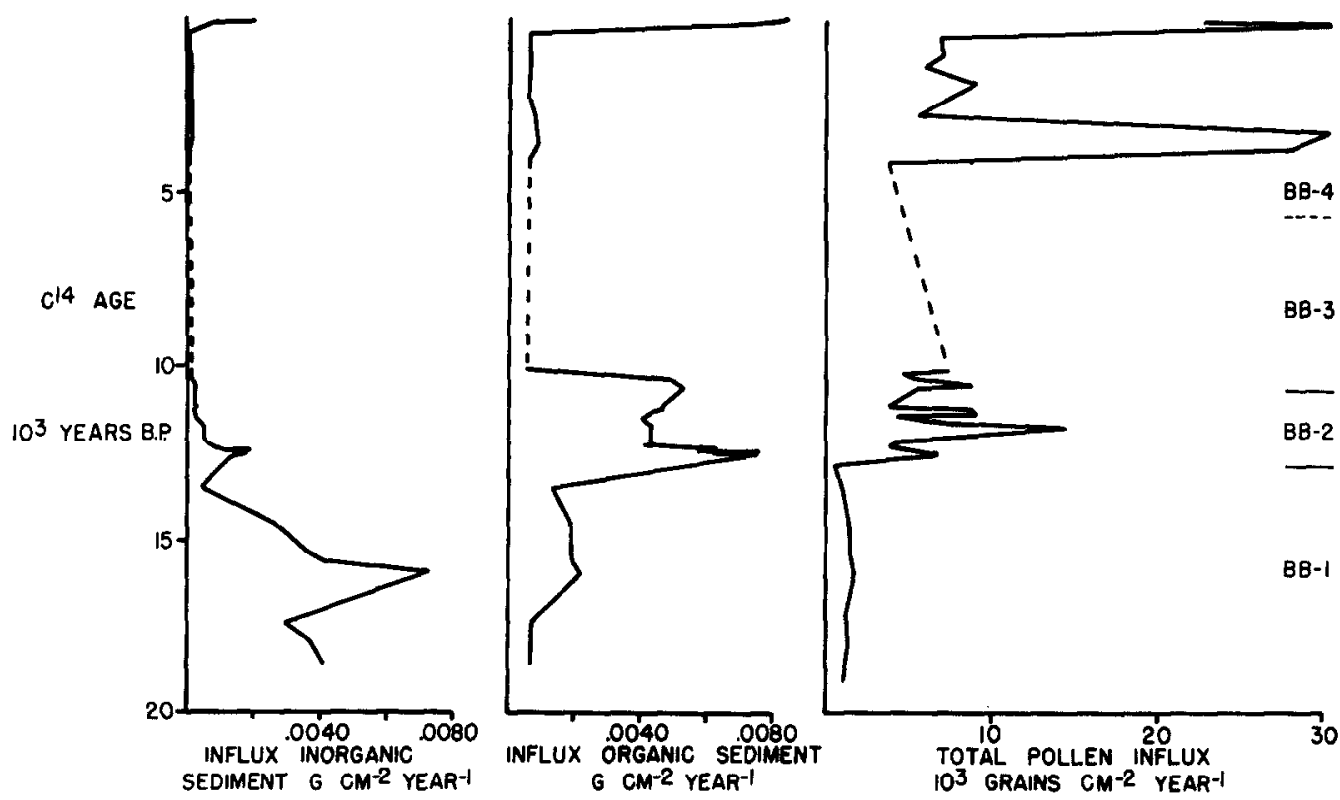

Fig. 7. Influx rates (amount accumulating per square centimeter per year) to Buckle's Bog over the last 19,000 yr. Inorganic sediment influx is in left-hand column; organic sediment, central column; and pollen influx, right-hand column. 
1000-2000 grains $/ \mathrm{cm}^{2}$ throughout the time interval from 19,000 to $12,500 \mathrm{yr}$ B.P. (260-200 cm).

During the same time interval, the rate of influx of inorganic sediment (ash weight per milliliter divided by deposition time) increased to a max at 16,000 B.P. $(250 \mathrm{~cm})$. Later it fell off again, declining to very small values after 10,000 B.P. (left-hand column, Fig. 7).

Influx of organic material (organic weight divided by deposition time) increased beginning 16,000 yr B.P., and then increased again, this time very sharply, $12,500 \mathrm{yr}$ B.P. $(200 \mathrm{~cm})$ as fibrous peat began to form (middle column, Fig. 6 ). The rate of influx remained high until 10,000 B.P. $(50 \mathrm{~cm})$ when deposition of fibrous peat stopped and humified peat began to accumulate at a very slow rate.

Meanwhile, changes in influx of pollen grains occurred independently of changes in the rate of accumulation of other components of the sediment. The low influx rate characteristic of the clay below $250 \mathrm{~cm}$ continues upward in the organic mud and peat (pollen concentration drops at these levels because of increased accumulation of inorganic and organic sediment); 12,500 years ago $(200 \mathrm{~cm})$ the rate of pollen influx increased sharply to $8000-10,000$ grains $/ \mathrm{cm}^{2}$. yr. Still higher rates of $10,000-30,000$ grains $/ \mathrm{cm}^{2} \cdot \mathrm{yr}$ are recorded in the upper, humified peat (above $50 \mathrm{~cm}$ ). Because there are no radiocarbon dates above $50 \mathrm{~cm}$, detailed variations in deposition time are not known. We believe some variations occurred, since there are variations in pollen concentration and the calculated rate of pollen influx. Pollen influx over the last $10,000 \mathrm{yr}$ should be studied at another site where there is a greater thickness of sediment.

\section{Pollen Stratigraphy}

The pollen diagram at Buckle's Bog has been divided into five pollen zones. Each zone shows characteristic percentages (Fig. 8 and 9) and rates of pollen influx (Fig. 10). The next section describes each zone and compares it to similar stratigraphic units at other sites in the Appalachians: Marsh (Martin, 1958a), New Paris (Guilday et al., 1964), and Bear Meadows (Sears, 1935), Pennsylvania; Round Glade (Guilday et al., 1964), Cranesville Swamp (Cox, 1968), and Cranberry Glades (Darlington, 1943), West Virginia; Saltville (Ray et al., 1967) and Hack and Quarles Ponds (Craig, 1969), Virginia; Singletary Lake, North Carolina (Whitehead, 1967); and the Bartow County Ponds, Georgia (Watts, 1970). Comparisons are made also to Rogers Lake (Davis, 1968) and other sites in the northeast (Davis, 1965), and to the Great Lakes sequence (Cushing, 1965 and 1967). The more important of these sites are indicated in Fig. 1.

Cyperaceae (sedge), Pollen Assemblage Zone BB-1

Sedimentary interval: 258-192 cm.

Radioacarbon age: $19,000-12,700$ yr B.P.

Description: Nonarboreal pollen (NAP) exceeds $50 \%$. Among the NAP types, sedge predominates ( $\geq$ $40 \%$ ), with grasses (2-14\%) being second in importance. Grains of $A r-$ temisia, Ranunculus, and Tubuliflorae are consistently present in low frequency. Spruce $(10-22 \%)$ and pine $(5-17 \%)$ are the dominant arboreal pollen (AP) contributors. Deciduous tree pollen occurs in low frequencies ( $<5 \%$ in each case). The occurrence of pollen grains of aquatics, primarily water milfoil (Myriophyllum) but also cattail (Typha) and pondweed (Potamogeton), is a further distinguishing feature of the zone.

Yearly pollen influx rate: $1000-2000$ grains $/ \mathrm{cm}^{2}$. 


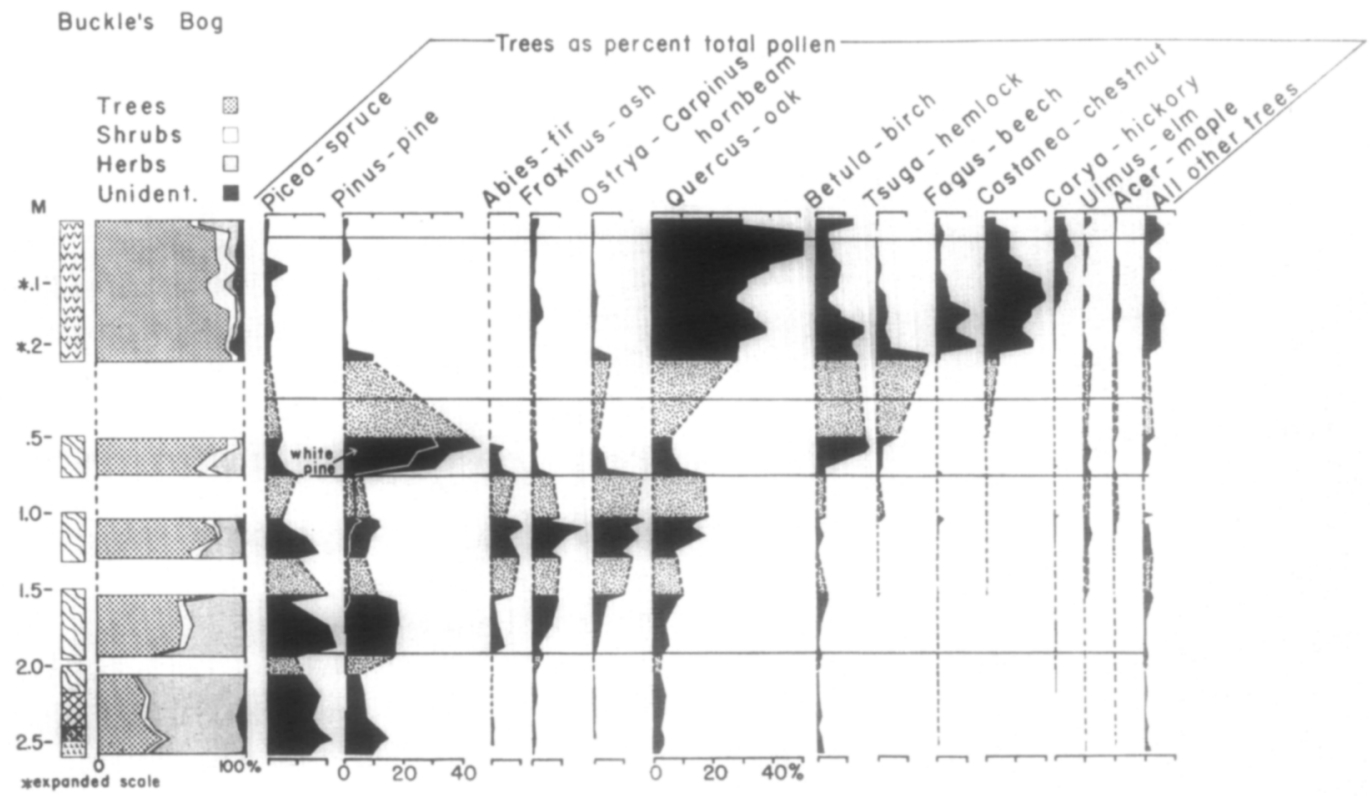

FIG. 8. Pollen percentage diagram from Buckle's Bog. Vertical scale is expanded for the upper 25 cm of the profile. Percentages are plotted against depth in the profile. Percentage sum includes pollen of all terrestrial plants (trees, shrubs, and herbs).

Stratigraphic comparison: Zone F-2 at Marsh and the lower two spectra at Round Glade offer close analogs to the Cyperaceae assemblage zone. The zone also resembles the basal herb assemblages at a number of sites in glaciated terrain (e.g., zone $\mathrm{T}$ of the New England pollen sequence [15,000-12,000 B.P.] and the Compositae-Cyperaceae assemblage zone of the Minnesota pollen sequence). An important difference is a higher ratio of spruce to pine pollen at Buckle's Bog than at late-glacial sites north of the drift border.

Comparison with surface samples: The Cyperaceae zone pollen assemblages differ markedly from the Allegheny plateau surface samples, even those collected from the surfaces of marshes where sedges now grow in abundance. Spruce pollen occurs in higher frequencies, and Cyperaceae pollen is far more abundant. Aquatics are present. The lower diversity and frequency of deciduous tree pollen is another difference. The fossil spectra are similar to the Mount Washington surface samples with regard to the frequencies of spruce, pine, fir, and oak, but contain very much less birch pollen and more pollen from herbs. They are more similar to modern assemblages from arctic regions (Davis, 1967; Ritchie and LichtiFederovich, 1967).

Comparison of pollen influx: Pollen influx values are similar to the basal herb zone (zone $T$ ) at Rogers Lake, and to measurements of modern pollen rain in arctic tundra (Ritchie and Lichti-Federovich, 1967). Pollen concentration is slightly lower than in samples from Lake of the Clouds (Table 1).

Picea-Pinus (spruce-pine), Pollen Assemblage Zone BB-2

Sedimentary interval: $192-76 \mathrm{~cm}$. 


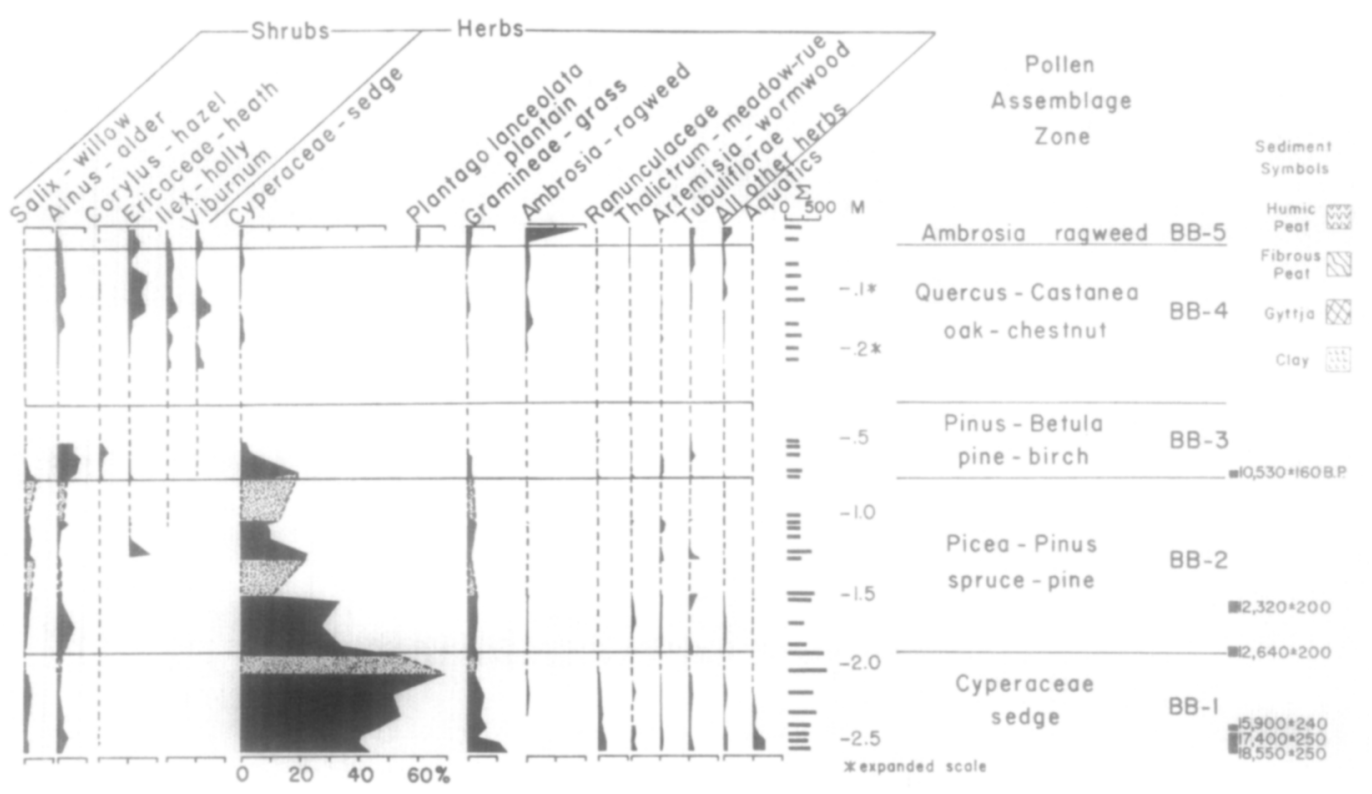

Fig. 9. Pollen percentage diagram from Buckle's Bog (continued).

Radiocarbon age : $12,700-10,500$ yr B.P. Description: Spruce, red and/or jack pine, and sedges (the dominant pollen types in the lower portion of the zone) show a trend of decreasing frequency. Fir, ash, hornbeam (Ostrya and/or Carpinus), and oak increase reciprocally, reaching peaks of $10,18,17$, and $18 \%$, respectively, in the upper levels of the zone. All but oak reach their maximum influx rate in this zone. In the upper portion of the zone, elm (Ulmus), maple, hickory, and beech (Fagus) are represented consistently for the first time, though at low frequencies. Birch and grass pollen are present throughout at frequencies of $\leq 5 \%$. Sedge influx is variable, while grass pollen was deposited at a rate higher than in BB-1. Ambrosia, Artemisia, and Tubuliflorae pollen becomes sporadic in occurrence.

Yearly pollen influx rate: $5000-10,000$ grains $/ \mathrm{cm}^{2}$.

Stratigraphic comparison: A spruce zone has been described at a number of sites. Zones 1 and 2 at Cranesville Swamp, the upper two spectra at Round Glade, the lowest two spectra at Cranberry Glades, the Saltville spectrum, zone F-4 at Marsh, and the basal clay and peat strata at Bear Meadows are the closest analogs to the spruce-pine zone assemblage at Buckle's Bog. In the Shenandoah Valley, Hack and Quarles Ponds show a Pinus-Picea (pine-spruce) zone with higher percentages of conifers and lower percentages of deciduous trees and herbs. The ratio of spruce to pine is very much lower there (about $3: 5$ ), and transitional between the ratio at Buckle's Bog $(2: 1)$ and the ratio at the much older pine-spruce zone at the fullglacial sites in northern Georgia, where pine was dominant $(1: 16)$. Another major difference between Buckle's Bog and Hack and Quarles Ponds concerns white pine pollen. At the latter sites white pine comprises 


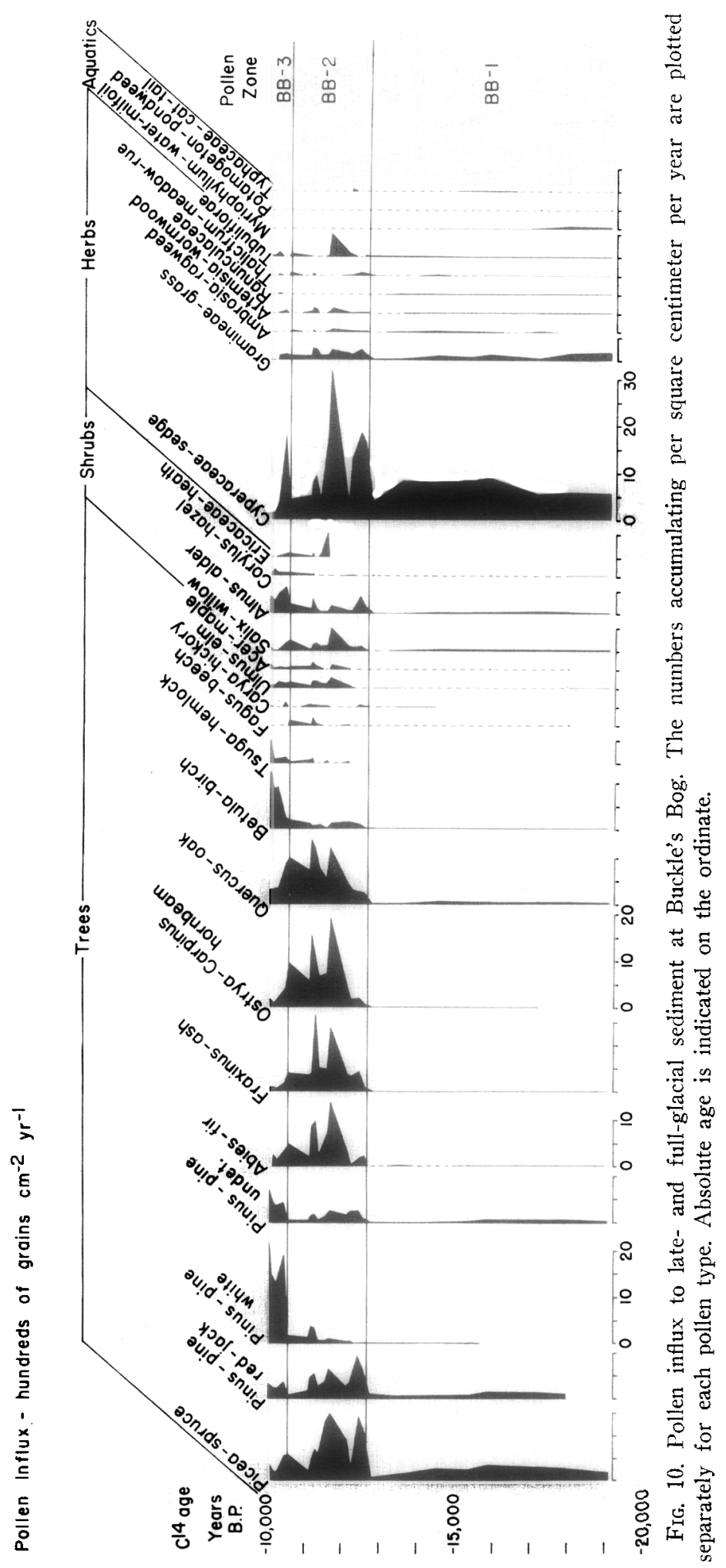


about $20 \%$ of the total pine pollen. White pine pollen is present in only minor amounts at Buckle's Bog.

The lower levels of the spruce-pine zone $(158-192 \mathrm{~cm})$ have some affinity with zones A-1, -2 , and -3 of the northeastern United States pollen sequence and the comparable zones of the northcentral sequence. As at these other sites, oak, ash, and horn-beam are the deciduous tree genera represented by the greatest abundance of pollen; their percentages and their rates of absolute influx, however, are higher at Buckle's Bog than in Connecticut. When the Picea-Pinus zone is considered as a whole, its transitional nature is evident. The trends are of increasing abundance of deciduous tree pollen and decreasing abundance of nonarboreal pollen. At Buckle's Bog, among the conifers only fir and white pine pollen increase in frequency; the pollen of both spruce and jack and/or red pine declines upwards. These trends are real: they occur also in the pollen influx diagram. This pattern contrasts with Connecticut, where absolute deposition of spruce pollen increases to a maximum in the upper part of the spruce zone (A-4), while deciduous tree pollen holds constant.

Comparison with surface samples: The fossil assemblages are unlike any of the surface samples collected on the Allegheny. They are more similar to the Mount Washington surface samples, although the correspondence is not complete, since the percentages of birch and alder are lower, and ash and hornbeam higher. Surface assemblages from boreal or arctic Canada fail to show such high percentages of deciduous tree pollen. In the lower levels of the zone, sedge pollen per- centages are much higher than in any surface samples in the Appalachians, resembling instead assemblages from tundra regions of the modern arctic (Ritchie and Lichti-Federovich, 1967).

Comparison of pollen influx: Pollen influx values are comparable to the rates observed for the spruce-larch (Larix) zone (zone I) at Rutz Lake in Minnesota (Waddington, 1969), about 5000 grains $/ \mathrm{cm}^{2}$, and for the spruce zone at Rogers Lake, about 10,000 grains $/ \mathrm{cm}^{2}$. Similar rates have been observed with pollen traps in the transition region between arctic tundra and boreal forest in northern Canada (Ritchie and Lichti-Federovich, 1967).

Pinus-Betula (pine-birch), Pollen Assemblage Zone BB-3.

Sedimentary interval: $76 \mathrm{~cm}$ to a depth less than $50 \mathrm{~cm}$. The top of the zone is truncated, the sediment presumably having been lost during the coring operation.

Radiocarbon age: Lower boundary, 10,500 yr B.P.; upper boundary, unknown.

Description: White pine pollen rapidly rises from 5 to $30 \%$, while total pine pollen reaches a maximum of $45 \%$. A maximum of birch pollen (18\%) occurs at the same stratigraphic level as the pine maximum. Fir, ash, hornbeam, and oak pollen sharply decrease in frequency and remain at relatively low percentage values throughout the zone. The $58-\mathrm{cm}$ level marks the last recorded appearance of fir in the profile. Hemlock pollen is for the first time consistently represented. Decreasing values of sedge pollen and sporadic occurrence of other herbaceous pollen types are recorded. Alder maintains a fre- 
quency value of 5-7\%. Hazel (Corylus) pollen is consistently present at low frequency values.

Yearly pollen influx rate: Not known with certainty, but may be similar to BB-2.

Stratigraphic comparisons: The pronounced increase of both white pine pollen and birch pollen percentages accords with the characteristic features of the pine-birch zone (zone B) of northeastern United States. Nearby sites fail to show the same sequence, however. Cox calls attention to the apparent absence of a pine-birch zone at Cranesville Swamp, but the sampling interval he used is broad enough to have missed the zone. At Cranberry Glades a pronounced rise of birch pollen percentages is associated with the first appearance of pine pollen. A rapid and marked increase in pine frequency values does occur at Marsh, though not at Bear Meadows, but a marked increase in birch pollen is absent.

Comparison with surface samples: The high pine pollen percentages render the BB-3 zone assemblages unlike any of the Allegheny plateau or Mount Washington surface samples. The fossil assemblages are, however, similar to surface samples collected in the transition zone between boreal and deciduous forests in central Canada, a similarity which Davis (1967) has noted already for the pine-birch pollen zone of the northeastern United States sequence.

Comparison of pollen influx: The very sudden increase in influx of white pine pollen and birch is similar to Rogers Lake. High influx also is recorded at comparable levels at Rutz Lake, Minnesota. The total influx values at Buckle's Bog are lower than at these other sites, however, by a factor of 3 or 4 . We believe that the lack of radiocarbon control may have led us to underestimate the sedimentation rate of the loose, fibrous peat of this zone, and consequently, to have underestimated the influx rate for pollen.

Quercus-Castanea (oak-chestnut), Pollen Assemblage Zone BB-4

Sedimentary interval: Less than 50 to 3 $\mathrm{cm}$. The base of the zone is truncated, the sediment presumably having been lost during the coring operation.

Radiocarbon age : $>5000$ to about 150 yr B.P.

Description: Deciduous tree pollen types arc most abundant. Oak pollen maintains a value of $>25 \%$ throughout the zone. First beech, then chestnut, and then hickory reach successive maxima of 14,20 , and $7 \%$, respectively. Grains of tupelo (Nyssa), butternut (Juglans cinerea), and basswood (Tilia) are recorded only for this zone and the stratigraphically overlying Ambrosia pollen zone. Spruce and pine pollen are present throughout at low frequency values $(<10 \%)$. Hemlock pollen rapidly decreases from a maximum of $22 \%$ at the base of the zone to a frequency of $<5 \%$. Birch pollen gradually decreases from a value of 15 to $<5 \%$. The pollen of a suite of shrubsEricaceae, Ilex, and Viburnum-is characteristic. Herb pollen makes up $5 \%$ of the total, of which Ambrosia in the only pollen type consistently represented.

Yearly pollen influx: Not known precisely, but varies between 10,000 grains $/ \mathrm{cm}^{2}$ and 30,000 grains $/ \mathrm{cm}^{2}$.

Stratigraphic comparisons: Zones C-1, -2 , and -3 at Cranesville Swamp offer a pollen stratigraphy nearly identical to zone BB-4 at Buckle's 
Bog. (Cranesville differs only in that maximum hemlock values are maintained until the rise in hickory pollen.) Comparable levels at Bear Meadows, Marsh, and Cranberry Glades differ only in detail. The appearance of chestnut pollen deep in the profile correlates with the pollen diagrams from Hack and Quarles Ponds, although the percentages are very much higher at Buckle's Bog. The chestnut curve differentiates the oak-chestnut pollen assemblage zone from the $\mathrm{C}$ zones of the northeastern United States sequence. In the latter, chestnut pollen remains in low frequency until the upper part of the stratigraphic sequence, where it riscs to a maximum of $5-10 \%$ (Deevey, 1939). At Buckle's Bog, the major increase in chestnut percentage value occurs immediately succeeding the hemlock maximum.

Comparison with surface samples: The oak-chestnut assemblages are similar to the Allegheny plateau surface samples. None of the latter, however, are comparable to the fossil assemblages in the lowest levels of the zone, which exhibit high hemlock percentages.

Comparison of pollen influx: Pollen influx values are roughly comparable to those from the C-zones at Rogers Lake and from correlative levels at Rutz Lake.

Ambrosia (ragweed), Pollen Assemblage Zone BB-5

Sedimentary interval: $0-3 \mathrm{~cm}$.

Absolute age: $150 \mathrm{yr}$ B.P. to present.

Description: Ambrosia pollen rapidly rises to a frequency value of $17 \%$. Oak pollen simultaneously decreases from 50 to $30 \%$. Other deciduous tree pollen types-beech, hickory, and chestnut-also exhibit decreasing percentages. Birch, however, in- creases in frequency from 4 to $13 \%$. The zone also is marked by the first appearance of grains of Plantago lanceolata. Sedges and grasses are represented consistently, though at low frequency.

Yearly pollen influx: Not known precisely.

Stratigraphic comparisons: This zone is missing from the Hack and Quarles Pond diagrams, which do not include the sediment surface. Stratigraphic analugs are identifiable, however, at sites geographically close to Buckle's Bog. In the uppermost $30 \mathrm{~cm}$ of sediment at Cranesville, Compositae (presumably Ambrosia) and grass frequcncies incrcase rapidly, while oak and pine frequencies decrease. A rapid and pronounced rise in the frequency of Compositae (presumably Ambrosia), grasses, sedges, and birch, and a corresponding decline in the frequency of black gum, pine, and oak occur in the uppermost $20 \mathrm{~cm}$ at Bear Meadows. Sampling and analysis of the upper levels of sediment at Marsh are necessary before the marked increase of NAP (including Ambrosia) and the marked decrease of AP (particularly oak and pine) near the base of the $\mathrm{C}$ zone can be stratigraphically correlated with zone BB-4. An assemblage zone near the surface of lake and bog sediments containing abundant Ambrosia pollen occurs throughout the northeast and the Great Lakes regions.

Comparison with surface samples: The surface sample of moss, and the sediment from 0 to $1 \mathrm{~cm}$ depth in the peat at Buckle's Bog yielded virtually identical spectra. The similarity gives some indication of the validity with which modern pollen assemblages preserved in and extracted from living moss can be compared with fossil 
pollen assemblages preserved in peat. High percentages of Ambrosia pollen are characteristic of all the surface samples from the Alleghenies.

\section{DISCUSSION}

\section{Vegetation and Climate}

\section{Pleistocene (Full-Glacial): 19,000-14,000 yr B.P.}

Buckle's Bog is one of the few sites in unglaciated eastern United States that is unequivocally full-glacial in age. The others are the Bartow County Ponds in northern Georgia (Watts, 1970) and the Carolina Bays (Whitehead, 1965, 1967). The basal samples from Hack Pond in the Shenandoah Valley (Craig, 1969) are older than $12,700 \mathrm{yr}$ and may be full-glacial in age. The same may be true for basal levels at a few other sites. Most of the supposedly full-glacial sites in the Appalachians, however, must be considered late-glacial in age. They contain abundant spruce pollen and correlate with the spruce-pine zone at Buckle's Bog $(10,500-12,700$ yr B.P.). The New Paris sinkhole and most of the Marsh Pennsylvania, site (Martin, 1958a; Guilday et al., 1964), for example, date from the time of glacial retreat. These sites record conditions after climatic warming had begun, not the full severity of climate at the time of the last glacial maximum.

In general, ecologists have underestimated the disruption and degree of change in plant and animal communities during the last glaciation. The magnitude of displacement of geographical ranges of species is greater than biogeographers had imagined. New evidence presented here and in other recent papers shows a broad tundra belt in the eastern United States, extending from the edge of the ice sheet at least $300 \mathrm{~km}$ southward at higher elevations along the Appalachian mountain chain. An alpine tundra must have existed still farther south on the high mountain summits (Fig. 1). For ex- ample, a similar pollen assemblage is found at Round Glade (one of the Cranberry Glades) at $3400 \mathrm{ft}(1000 \mathrm{~m})$ elevation, 160 $\mathrm{km}$ southwest of Buckle's Bog. Note that Buckle's Bog, which shows clear evidence for tundra, is not in mountainous terrain. Its elevation is only $2700 \mathrm{ft}(810 \mathrm{~m}$ ) (Fig. 1 ). The landscape is plateau country, with a few steep-sided valleys (Fig. 2). The $\mathrm{Cy}$ peraceae (sedge) pollen assemblage (BB-1) deposited between 18,500 and 12,700 B.P. can only be accounted for by the existence of tundra all across the top of the plateau. The assemblage is similar to what we find now in modern tundra regions in the arctic. It is not similar to modern pollen assemblages from glades located within forested regions, nor from modern prairie. A most important comparison is with pollen assemblages from above tree line on Mount Washington. The Mount Washington samples have high percentages of tree pollen of a variety of species, blown up onto the alpine zone from forest at lower elevations (Fig. 4). The Cyperaceae assemblage at Buckle's Bog, in contrast, contains small relative and absolute amounts of tree pollen (Figs. 9 and 10), suggesting an area of treeless tundra very much larger than the $20-\mathrm{km}^{2}$ alpine area (Bliss, 1963) on Mount Washington and the other summits of the Presidential massif.

The altitude of the tree line on the Alleghenies during full-glacial time is a matter of major interest. A high ratio of spruce pollen to pine pollen is characteristic for the Cyperaceae assemblage at Buckle's Bog. Large numbers of spruce grains relative to pine occur also in the Mount Washington samples. The high ratio at Buckle's Bog suggests that forest was not far distantthat is, trees must have grown at lower elevations, perhaps within a 10 - to $25 \mathrm{~km}$ radius of the site. Otherwise, we would see a preponderance of easily transported pine pollen, as in samples from modern high arctic tundra, or from alpine regions far above 
the forest limit (Maher, 1963). This appears to be the case in Connecticut, where spruce pollen is much rarer relative to pine in the late-glacial herb pollen zone. The absolute influx of spruce pollen is also only about half as high in Connecticut as at Buckle's Bog. The Connecticut site was perhaps $100 \mathrm{~km}$ or more from any forest. The Buckle's Bog site, however, must have been closer to spruce forests growing at low elevations in Maryland and Virginia. Forests probably were growing in the valley and ridge region just east of the Alleghenies. Spruce may have been confined to elevations below $1500 \mathrm{ft}(450 \mathrm{~m})$, in which case it was altogether absent from the Allegheny plateau. Alternatively, spruce might have extendcd up into the high valleys, such as the Middle Fork river valley, a few kilometers from Buckle's Bog (Fig. 2). Pollen diagrams from sites at a series of intermediate elevations eventually will show where the tree line was, locating the ecotone between the tundra that existed at $2700 \mathrm{ft}(800 \mathrm{~m})$ near Buckle's Bog and the forests (apparently mixed spruce and pine) that grew at $1000 \mathrm{ft}(300 \mathrm{~m})$ in the Shenandoah Valley near Hack and Quarles Ponds.

The coastal plain and piedmont further south also were forested at this time. In these forests the proportion of spruce was very much less than in the Shenandoah Valley; although spruce was present, jack pine was the dominant tree (Watts, 1970). Localities where temperate deciduous trees survived the glaciation are as yet unknown in the eastern United States.

The full-glacial forest communities of eastern North America were different from modern boreal forest, especially the boreal forests of eastern Canada, where fir is relatively abundant and jack pine is rare. Before these recent data came to light, biogeographers visualized a southward displacement of existing vegetation formations (Martin, 1958b; Dillon, 1956). But this simple scheme is insufficient to explain the full- glacial distribution of forest trees. Fullglacial communities were different both in species composition and species abundances from any modern vegetation. This difference has a further implication: the modern Canadian boreal forest is a new formation-a recent development. The combinations of species, and species frequencies that characterize its communities are of recent, Holocene origin, rather than a product of long-term community evolution. The recent origin of forest communities has been emphasized recently by Watts (1970) and by Craig (1969). Sjörs (1963) came to the same conclusion using biogeographic evidence from the modern boreal forest.

In an interesting paper, Bryson (1966) has scarched for climatic parameters, such as the mean position of the polar front, that are correlated with the boundaries of the modern boreal forest. Bryson and Wendland (1967) used these parameters to reconstruct late-Pleistocene climate, basing a part of their interpretation on the boundaries of the boreal forest in late-glacial time, as reconstructed by paleoecologists. This method might be used for full-glacial climate, except that the coniferous forest of full-glacial time (also late-glacial, as will be discussed later) was not really comparable to the modern boreal forest. Perhaps the difference in community composition is not significant at the level of resolution attempted by Bryson and Wendland. However, the difference in vegetation communities could be important. implying a uniquely different climatic regime at these low latitudes.

Changes in plant or animal communities pose a problem for paleoecologists. When ancient communities have no modern ana$\log$, reconstructions of paleoclimate have to be based to a larger extent on individual species. In the example previously discussed, climatic parameters might be correlated with the range boundaries of single tree species, and the reconstruction of paleoclimate could proceed on this basis. The use 
of single species has disadvantages, too, which are seldom discussed in the paleoecological literature. In nature, species do not live in isolation, but instead, interact with other species. Each occurs most abundantly in those environments where it has a competitive advantage over other species. In the absence of a competing species, as in a different community, a species might be found growing abundantly over a different (and perhaps wider) range of physical conditions. Predators (for example, insects on plants) have a similar effect, limiting the plant to a part of the range of conditions in which it might potentially survive. This is why there is strength to environmental reconstructions based on the entire community. Changes in communities, both in numbers of species and their relative abundances, can be fortuitous, for example, caused by the absence of species due to slow migration. Or, changes in communities may be brought about by changes in physical environment, such as climate. The affect of these physical changes will be difficult to decipher unless the interactions among species are sufficiently well understood to be taken into account.

\section{Late-Pleistocene (Late-Glacial): 14,000 10,000 YR B.P.}

A series of changes in vegetation occurred in the southeastern United States at the time the Wisconsin ice sheet began to retreat. Some of these changes are timetransgressive, beginning in the south and moving northward; others may be synchronous over large areas. In the latter case, sudden, step-type climatic changes (Bryson, 1970) may, or may not, be involved. A sudden vegetation change can result from a sudden rise in temperature, or from a gradual and continuous rise as the temperature crosses a threshold for a number of species.

The earliest change at any of the sites we are discussing occurred $16,000 \mathrm{yr}$ B.P. This was an increase in influx of both inorganic and organic matter to sediments of the lake which then occupied the site of what is now Buckle's Bog. The change was probably only local and was perhaps caused by a change in the hydrology of the site.

In Georgia there was an important change from coniferous to deciduous forest beginning at 13,600 B.P. The percentage of pine pollen decreases and oak pollen begins to increase. Unfortunately, we do not have radiocarbon dates to indicate how much time elapsed before the change was completed, with pine pollen becoming rare and oak becoming the dominant pollen species. No detectable change occurred at Buckle's Bog at the time changes began to occur in Georgia, but in the Shenandoah Valley, white pine pollen increased in percentage. One thousand years later, 12,700 yr B.P., while the changes in Georgia were presumably still in progress, events are recorded both in the Shenandoah Valley and at Buckle's Bog. In the Shenandoah Valley, the pollen change is a minor one, but is recognized by Craig as a boundary between two subzones of the $P i$ nus-Picea pollen zone. Pollen from deciduous species, notably oak and hazel (Cory$l u s$ ), increases, while pollen from Isoetes and Sanguisorba decreases. At Buckle's Bog, 12,700 B.P., a major change occurred-tree pollen sharply increased. Both the absolute influx and the percentage rose sharply. Willow, alder, and heath pollen also are deposited in greater numbers than before. These changes represent replacement of tundra vegetation by boreal woodland and shrubs. We bclicve that spruce and jack and/or red pine, and possibly fir, grew for the first time locally in close proximity to Buckle's Bog. The climate at this elevation had changed from a tundra climate to one favorable to the growth of trees. The change is synchronous with a change affecting different plants in the Shenandoah Valley.

At approximately the same time, in the vicinity of Rogers Lake, Connecticut, tundra was replaced by woodland. The synchroneity, or lack of it, in the rather similar series 
of pollen changes at Buckle's Bog and Rogers Lake is important in deciding whether a stepwise change was felt simultaneously over a large area or a time-transgressive change moved from south to north. In the latter case, the change could have occurred either as the result of gradual warming (the threshold for tree growth being reached first at southerly latitudes) or as the result of a warming trend that began first in the south and then began later in the north. The change from tundra to woodland is dated in Connecticut at 11,800 corrected radiucarbon years, almost $1000 \mathrm{yr}$ later than in Maryland. Unfortunately, we cannot know whether or not the difference in date is significant. Because Rogers Lake now contains nonequilibrium carbon (apparently derived from carbonate rocks in the vicinity), all dates from the sediment at Rogers Lake have had $730 \mathrm{yr}$ subtracted as a correction, assuming that nonequilibrium carbon always has comprised the same proportion of the organic sedimentary carbon. Without this correction, events correlate with Buckle's Bog; with the correction, the events at Rogers Lake occurred slightly later. To test for synchroneity, soft-water lakes or terrestrial peat deposits without this kind of error should be utilized. A series of welldated pollen profiles along a transect from south to north would answer this important question.

Another important question that has never been adequately resolved concerns pollen from temperate deciduous trees in late-glacial sediment. Wright (1971) believes that deciduous trees grew together with conifers in late-glacial forests. We believe that in the east, temperate trees were absent from the spruce-pine woodlands, and that the conifers grew as an open woodland, with widely spaced trees. This vegetation would be similar in aspect to the open woodland in northern Quebec (e.g., the Ungava), in the transition region between forest and arctic tundra (Terasmae and Mott,
1965), where analogous pollen assemblages are found. The woodland did not produce much pollen, as the low rate of pollen influx implies. Similarly low rates of pollen production also have been measured in modern open boreal woodland in Canada (Ritchie and Lichti-Federovich, 1967). Since so few pollen were produced locally, windblown pollen carried in from distant forests could have comprised a considerable percentage of the total. Supporting this point of view is the fact that the percentage of deciduous tree pollen in 10,000 - to 12,000 -yr-old sediment is higher $(30 \%)$ at $2700 \mathrm{ft}(800 \mathrm{~m})$ elevation at Buckle's Bog than at $1000 \mathrm{ft}$ $(300 \mathrm{~m})$ elevation $(12-18 \%)$ in the Shenandoah Valley. We believe this reflects the low pollen productivity of the local spruce and jack pine woodland growing on top of the plateau. Presumably spruce forest and white pine grew in dense forests at lower elevations. The greater amounts of locally produced pollen there diluted the windblown component. The alternative explanation, which we find unacceptable, is that oak, ash, and hornbeam were more abundant at higher elevations. It makes no sense to think of temperate deciduous trees as being more abundant relative to spruce on the high plateaus than on hills and valleys at lower elevations. Measurement of pollen influx to sites at low elevations would be helpful in proving this point.

The preceding hypothesis does not explain why deciduous tree pollen shows a sharp increase in absolute influx, both at Buckle's Bog and Rogers Lake, at the time the local vegetation changes from tundra to woodland (12,000-13,000 B.P.). What does the increased influx of pollen mean? We are hesitant to believe it means only that deciduous forests moved closer to the sites. Forest began to move into Georgia to replace pine forest a thousand years before this, but we do not find the change reflected as increased influx of oak pollen to sites farther north. We are led to suggest instead that 
there might have been a change in prevailing wind direction at 12,700 B.P. This change in circulation pattern and climate might have caused larger amounts of pollen to be blown eastward from a source area in the central plains of North America. Grüger (1970) has shown that oak pollen was important in southern Illinois throughout the Wisconsin glaciation. This region, or regions to the south of it, could have become a source for deciduous tree pollen as the pattern of air mass trajectories shifted, in conjunction with the northward retreat of the margin of the ice sheet. Oak, ash, and hornbeam occur in greater absolute amounts, as well as in higher percentages, at Buckle's Bog than at Rogers Lake. This information is compatible with the idea that Buckle's Bog was nearer the source. Admittedly, this explanation is highly speculative, but it could be tested with a large number of pollen investigations in the southern Appalachians and westward into the central plains.

Fossil mammals have been identified from findings at a number of caves and sinkholes in the Appalachians. In most cases the absolute age is unknown, although the northern aspect of the faunas has suggested Pleistocene age. Arctic and subarctic animals like caribou, known from Tennessee (Guilday $e t$ al., 1964), may date from a full-glacial time when tundra extended far south at high elevations. However, several of the other sites contain late-glacial material. The Saltville site, which contains bones of musk-ox, mastodon, woolly mammoth, bison, and caribou (Ray et al., 1967), has pollen (in association with a musk-ox) similar to the PiceaPinus assemblage at Buckle's Bog. A radiocarhon date on a mammoth tusk, $13,460 \pm$ 420 B.P. (SI 461) (C. E. Ray, personal communication) is on the borderline between full- and late-glacial, however. Pollen from the New Paris sinkhole in Pennsylvania (located about $380 \mathrm{ft}$ [115 m] elevation, $100 \mathrm{~km}$ northeast of Buckle's Bog), as well as radiocarbon dates, correlate with the late-glacial Picea-Pinus assemblage. At the New Paris sinkhole, which has been studied in great detail, the fauna is predominantly boreal, but it includes one truly arctic species (collared lemming) and two prairie species (thirteen-lined ground squirrel and sharp-tailed grouse) (Guilday et al., 1964). Fossils from mammal species that still range into Pennsylvania are different in size from the modern populations, resembling instead the size of modern boreal populations of these species in Canada and Alaska. These animals display a "Bergmann response" today, with body size increasing with latitude. The large size of individuals in the fossil population reinforces the impression given by the species composition of the fauna : a cold climate is indicated. An open, boreal woodland, perhaps with tundra persisting on a few exposed ridge-top sites, is compatible with the New Paris fauna.

In summary, during the period between 12,700 and $10,000 \mathrm{yr}$ B.P., spruce woodland (with some jack pine?) grew at higher elevations in the Alleghenies, while forests that were still predominantly coniferous, but included white pine, grew at $1000 \mathrm{ft}(300 \mathrm{~m})$ elevation in the Shenandoah Valley. To the south, a mixed forest, with spruce, pine, and hardwoods, including birch, had replaced the full-glacial forest of jack pine and spruce. Farther north, in Pennsylvania (??), Connecticut, and Massachusetts (and probably still farther north in New England), the woodland was open, with spruce and possibly some jack (or red) pine. The character of the vegetation seems to have been very similar on the Alleghenies and in southern and central New England-an enormous area with essentially similar vegetation. But west of the Appalachians, in the central part of the continent, the late-glacial coniferous forests were dominated by spruce. By this time, spruce already had been replaced by prairie in the central Great Plains, and the spruce-dominated forest was 
moving northward in a belt in the wake of the retreating ice sheet (Wright, 1970).

\section{Holocene (Postglacial): 10,500 YR B.P. to Present}

The Holocene period begins at 10,500 B.P. at Buckle's Bog with the replacement of spruce woodland by mixed coniferousdeciduous forest. A similar boundary, usually recognized by the decline of spruce pollen, ranges from 12,000 to $9000 \mathrm{yr}$ in age at sites in the Middle West (Wright, 1970). At Buckle's Bug, early Holocene pollen assemblages resemble modern assemblages from south-central Canada, northeast of the Great Lakes but south of the boreal forest (Davis, 1967, 1969). The most striking change in the profile is the sharply increased influx of white pine pollen. This change cannot represent a simple migration of white pine, because the species was present (contributing up to $10 \%$ of the PinusPicea assemblage) more than $2000 \mathrm{yr}$ earlier in the Shenandoah Valley (Craig, 1969). The sudden increase at Buckle's Bog represents a change in climate. Although the range of white pine overlaps with many boreal trees, it is not a boreal species. It is much more common in the mixed deciduous forests, such as those of central New England and northern Michigan.

At Rogers Lake the increase in white pine pollen at the beginning of the Holocene period is accompanied by increased rates of influx for oak, poplar (Populus), and maple pollen. The latter changes are not visible at Buckle's Bog. It seems likely that all the estimates of absolute pollen influx are too low at this level in the profile, because of an underestimation of the sedimentation rate of the coarse and uncompacted peat. Unfortunately, we have no radiocarbon dates above the lower boundary of this zone.

Because the pollen diagrams are so similar, it is tempting to believe that the rise of white pine occurred at the same time at Buckle's Bog and Rogers Lake. In fact, there is almost a $1000 \mathrm{yr}$ difference in the radiocarbon dates from the two sites. As we have discussed previously, the difference may or may not be significant, since the Rogers Lake dates had to be corrected for the presence of nonequilibrium carbon in the modern lake.

In the Shenandoah Valley, a major change occurred 9500 yr B.P., when the percentage of oak and hemlock pollen rose steeply and that of pine and spruce declined, indicating a change from conifer forest to hardwood forest (Craig, 1969). Again, we are unsure whether this change is significantly different in age from the rise in white pine pollen at Buckle's Bog.

The younger part of the Buckle's Bog profilc, the Quercus-Castanea pollen assemblage zone, persists in a striking resemblance to the New England pollen sequence. The classic work in that area (Deevey, 1939) recognized three oak pollen zones overlying the pine-birch zone described previously. These are $\mathrm{C}-1$, oak-hemlock; $\mathrm{C}-2$, oak-hickory; and C-3, oak-chestnut. These zones were supposed to represent three different climatic regimes. Comparison with the Maryland and Virginia sites suggests they represent, at least in part, the late arrival of forest tree species migrating from the south. In the Alleghenies and the Shenandoah Valley, chestnut pollen appears very much earlier, although the rest of the sequence is roughly similar, with successive maxima of hemlock, beech, and hickory. The late appearance of chestnut in Connecticut, then, may have resulted from a very slow migration rate for this species. It grew in Maryland in mid-Holocene time, but appeared in Connecticut just 2000 yr B.P. Southern Connecticut and the region around Buckle's Bog are similar in vegetation, both areas being mapped by Braun (1950) as "oak-chestnut" forest. The forest community was constituted several thousands of years ago on the Allegheny plateau, but only recently in Connecticut. Unfortunately, 
extensive disturbance of the forests and the near-extinction of chestnut from blight prevent a study of the dynamics of these forest communities, and analysis of the affect the arrival of a new, dominant tree species may have had on community structure.

The uppermost Ambrosia assemblage is the reflection of logging and farming in the last $150 \mathrm{yr}$ (Shreve, 1910).

\section{CONCLUSIONS}

The Appalachian mountains are important in the history of the American flora. Biogeographers have argued about the extent to which northern species penetrated southern plant communities. They have disputed whether the deciduous forests changed in composition, contracted in area, or moved southward in response to climatic changes accompanying the glaciation (Braun, 1950; Deevey, 1949; Martin, $1958 \mathrm{~b})$. But there has been general agreement that the topographic diversity of the north-south trending mountains and intervening valleys provided migration routes for retreat and readvance of flora and fauna with each glaciation. This situation has been contrasted to Europe, where east-west trending mountains, themselves covered with ice caps, were barriers to southward movement of temperate species. The difference in topography of the two continents is the standard explanation for the difference in floral diversity. Many temperate species and genera (like hickory, hackberry [Celtis] and hemlock) became cxtinct in Europe during the Pleistocene. In America the forests have remained species-rich from the Tertiary to the present.

Very recent data show, however, that the Mediterranean region of Europe, previously envisioned as a vast refugium for temperate species, was dry and cold during glacial intervals. Only small areas (along the southern flanks of the Alps?) were suitable for the growth of temperate deciduous trees (van der Hammen et al., 1971). The lim- ited area of refugia, and the small numbers of individuals surviving there, may have been as important as the lack of migration routes in causing extinctions.

Our thinking now should be appropriately revised regarding the Appalachians and their role in the preservation of the deciduous forests of North America. Braun has emphasized that the well-established, closed deciduous forest communities of the Appalachians would have discouraged the establishment of immigrant species from the glaciated region. This idea inplies that extensive climatic changes occurred only in the region actually covered by ice. The newer fossil evidence, including the data presented in this paper, shows that large changes in climate occurred throughout the Appalachians. These changes disrupted the existing vegetation, and allowed immigrants from the north, better adapted to the new climatic regime, to establish themselves. We believe that Braun is correct in emphasizing the north-south continuity of habitats with similar topography and altitude. Surely this facilitated the southward movement of species as the climate deteriorated. The change of climate, however, was undoubtedly not a simple southward displacement of existing weather patterns. Nor did the flora move as intact plant communities. Whatever the role of competition between existing vegetation and new migrants from the north, conditions during the late-Wisconsin were such that the deciduous forest was extirpated completely from the Appalachian mountains. The tree species survived elsewhere. Braun's idea that the mixed mesophytic deciduous forest community had remained in the Appalachians, virtually unchanged, since the early Tertiary, is no longer tenable. The remarkable diversity of the flora must have some other explanation than stability over a long interval of time.

Meanwhile, we are still without a clear idea of the location of a refuge for temperate deciduous trees. Perhaps the survival of 
so many species implies that, in contrast to Europe, the refugium (or refugia) was a large one, with a variety of habitat. Tracing the history of deciduous forest species as they moved southward (and westward?) during each glacial period, and northward again in the wake of the retreating ice, is a challenge to future study.

\section{ACKNOWLEDGMENTS}

This work was supported in part by National Science Foundation Grant GB 7727. We acknowledge with gratitude the radiocarbon dates from the Yale Radiocarbon Laboratory made available to us by Dr. Minze Stuiver.

We also acknowledge our appreciation to Mr. Harvey Buckle for permission to core on his land and to Dr. Henry Wright of the Museum of Anthropology, University of Michigan, for directing our attention and interests to the sediments of Buckle's Bog.

Linda Brubaker and Henry and Fran Wright contributed valuable field assistance.

\section{REFERENCES}

BenNinghofF, W. S. (1962). Calculation of pollen and spore density in sediments by addition of exotic pollen in known quantities. Pollen et Spores 4, 332-333.

Butss, L. C. (1963). Alpine plant communities of the Presidential range, New Hampshire. Ecology 44, 678-697.

Braun, E. L. (1950). "Deciduous forests of eastern North America." Hafner, New York.

Broecker, W. S., and Walton, A. (1959). The geochemistry of $\mathrm{C}^{14}$ in fresh-water systems. Geochimica Cosmochimica Acta 16, 15-38.

Bryson, R. A. (1966). Air masses, streamlines, and the boreal forest. Geographical Bulletin 8, 228-269.

BRYSON, R. A. (1970). The character of climatic change and the end of the Pleistocene. American Quaternary Association Abstracts, 20-22.

BRYson, R. A., AND Wendland, W. M. (1967). Tentative climatic patterns for some late-glacial and post-glacial episodes in central North Amcrica. In "Life, Land and Water." (W. J. Mayer-Oakes, Ed.), pp. 271-298. University of Manitoba Press, Winnipeg.

Cox, D. D. (1968). A late-glacial pollen record from the West Virginia-Maryland border. Castanea 33, 137-149.
Craig, A. J. (1969). Vegetational history of the Shenandoah Valley, Virginia. Geographical Society of America, Inc., Spec. Paper 123, 283-296.

Cushing, E. J. (1965). Problems in the Quaternary phytogeography of the Great Lakes region. In "The Quaternary of the United States." ( $\mathrm{H}$. E. Wright, Jr., and D. G. Frey, Eds.), pp. 403-416. Princeton University Press, Princeton, NJ.

Cushing, E. J. (1967). Late-Wisconsin pollen stratigraphy and the glacial sequence in Minnesota. In "Quaternary Paleoecology." (E. J. Cushing and H. E. Wright, Jr., Eds.), pp. 59-88. Yale University Press, New Haven, Conn.

Darlington, H. C. (1943). Vegetation and substrate of Cranberry Glades, West Virginia. Botanical Gazette 104, 371-393.

Davis, M. B. (1965). Palynology and phytogeography of northeastern United States. In "The Quaternary of the United States." (H. E. Wright, Jr., and D. G. Frey, Eds.), pp. 377-401. Princeton University Press, Princeton, NJ.

DAvis, M. B. (1966). Determination of absolute pollen frequency. Ecology 47, 310-311.

Davis, M. B. (1967). Late-glacial climate in northern United States: A comparison of New England and the Great Lakes region. In "Quaternary Paleoecology." (E. J. Cushing and H. E. Wright, Jr., Eds.), pp. 11-43, Yale University Press, New Haven, Conn.

Davis, M. B. (1969). Climate changes in southern Connecticut recorded by pollen deposition at Rogers Lake. Ecology 50, 409-422.

Davis, M. B., and Deevey, E. S., JR. (1964). Pollen accumulation rates: Estimates from lateglacial sediment of Rogers Lake. Science 145, 1293-1295.

DeEvey, E. S., JR. (1939). Studies on Connecticut lake sediments: I. A postglacial climatic chronology for southern New England. American Journal of Science 237, 691-724.

DeEvey, E. S., JR. (1949). Biogeography of the Pleistocene: I. Europe and North America. Geological Society of America Bulletin 60, 1315-1416.

Deevey, E. S., JR., Gross, M. S., Hutchinson, G. E., and KrAYBiLl, H. L. (1954). The natural $\mathrm{C}^{14}$ contents of materials from hard-water lakes. Proceedings of the National Academy of Science 40, 285-288.

Dillon, L. S. (1956). Wisconsin climate and life zones in North America. Science 123, 167-176.

FaEgri, K., AND IVERSEn, J. (1964). "Textbook of Pollen Analysis," 2nd ed. Munksgaard, Copenhagen. 
GrüGER, E. (1970). The development of the vegetation of southern Illinois since late-Illinoian time (preliminary report). Revue Geographie Physique et de Geologie Dynamique (2), 12, Fasc. 2, 143-148.

Guilday, J. E., Martin, P. S., and McCrady, A. D. (1964). New Paris No. 4: A latePleistocene cave deposit in Bedford County, Pennsylvania. National Speleological Society Bulletin 26, 121-194.

Hammen, T., van Der, Wijmstra, T. A., and ZAGWIGN, W. H. (1971). The floral record of the late-Cenozoic of Europe. In "The Late Cenozoic Glacial Ages." (K. K. Turekian, Ed.), pp. 391-424. Yale University Press, New Haven, Conn.

Maner, L. J. (1963). Pollen analyses of surface materials from the southern San Juan mountains, Colorado. Geological Society of America Bulletin 74, 1485-1503.

MarTin, P. S. (1958a). Taiga-tundra and the fullglacial period in Chester County, Pennsylvania. American Journal of Science 256, 470-502.

Martin, P. S. (1958b). Pleistocene ecology and biogeography of North America. In "Zoogeography." (C. S. Hubbs, Ed.), pp. 375-420. American Association for the Advancement of Science, Pub. 51.

Mathews, E. B. (1933). Geological map of Maryland. Maryland Geological Survey 2/380 160.

Ray, C. E., Cooper, B. N., and Benninghoff, W. S. (1967). Fossil mammals and pollen in a late Pleistocene deposit at Saltville, Virginia. Journal of Paleontology 41, 608-622.

Ritchie, J. C., ANd Lichti-Federovich, S. (1967). Pollen dispersal phenomena in arctic-subarctic Canada. Review of Palaeobotany and Palynology 3, 255-266.

SeArs, P. B. (1935). Types of North American pollen profiles. Ecology 16, 488-499.

Shreve, F. (1910). The ecological plant geography of Maryland, Mountain Zone. In "Maryland
Weather Service." Vol. 3, pp. 275-294. Johns Hopkins University Press, Baltimore, Md.

SJörs, H. (1963). Amphi-Atlantic zonation, Nemoral to Arctic. In "North Atlantic Biota and Their History." (A. Löve and D. Löve, Eds.), pp. 109-126. Pergamon, New York.

Terasmae, J., And Mott, R. J. (1965). Modern pollen deposition in the Nichicun Lake area, Quebec. Canadian Journal of Botany 43, 393-404.

U.S. Department of Agriculture (1941). "Climate and Man." Clearinghouse, Washington, DC.

VISHER, S. S. (1966). "Climatic Atlas of the United States." Harvard University Press, Cambridge, Mass.

WAduington, J. C. B. (1969). A stratigraphic record of the pollen influx to a lake in the Big Woods of Minnesota. Geological Society of America, Spec. Paper 123, 263-282.

Watrs, W. A. (1969). A pollen diagram from Mud Lake, Marion County, northcentral Florida. Geological Sociely of America Bulletin 80, 631642.

Watrs, W. A. (1970). The full-glacial vegetation of northwestern Georgia. Ecology 50, 17-33.

Watts, W. A. (1971). Postglacial and interglacial vegetation history of southern Georgia and central Florida. Ecology 52, 676-690.

Whitehead, D. R. (1965), Palynology and Pleistocene phytogeography of unglaciated eastern North America. In "The Quaternary of the United States." (H. E. Wright, Jr., and D. G. Frey, Eds.), pp. 417-432. Princeton University Press, Princeton, NJ.

WhiteheAd, D. R. (1967). Studies of full-glacial vegetation and climate in southeastern United States. In "Quaternary Palcoecology." (E. J. Cushing and H. E. Wright, Jr., Eds.), pp. 237248. Yale University Press, New Haven, Conn. WRIGHT, H. E., JR. (1970). Vegetational history of the central plains. In "Pleistocene and Recent Environments of the Central Great Plains," Spec. Pub. 3, pp. 157-172. University Press of Kansas, Lawrence, Kansas. 